Published in "Dalton Transactions 42(1): 217-231, 2013"

which should be cited to refer to this work.

\title{
Rings, chains and helices: new antimicrobial silver coordination compounds with (iso-)nicotinic acid derivatives $\dagger$
}

\begin{abstract}
Inès Chevrier, ${ }^{a}$ Jorge L. Sagué, $\neq^{\mathrm{a}}$ Priscilla S. Brunetto, ${ }^{\mathrm{a}}$ Nina Khanna, ${ }^{\mathrm{b}}$ Zarko Rajacic ${ }^{\mathrm{b}}$ and Katharina M. Fromm*a

Complexes with silver ions have great potential for applications in medicine. Appropriate bidentate ligands, binding to silver ions, are able to generate coordination polymers as well as molecular entities as a function of ligand flexibility, conformation and length. Here we present the continuation of our previous studies in this field with ligands based on oligomers of polyethylene glycol, functionalized at both ends with either nicotinic or isonicotinic acid. The structures of three ligands and nine new coordination compounds are presented. A large variety of structures are obtained as a function of counterion, solvent and ligand-to-metal ratio, such as isolated rings, offset stacked rings, parallel chains and entangled chains, and their antimicrobial properties as well as biocompatibility are assessed.
\end{abstract}

\section{Introduction}

"Metal-organic frameworks or networks" (MOFs) or "metalorganic coordination polymers" are compounds based on the coordinative interaction of metal ions or clusters with charged or neutral organic ligands. ${ }^{1-3}$ Depending on the metal, its oxidation state and coordination number, and depending on the ligand functionality and flexibility, a large panel of geometries can be obtained. The metal ions or clusters, acting as nodes, can be linked via the ligands into one- $(1 \mathrm{D}),{ }^{4}$ two- $(2 \mathrm{D})^{5}$ or three-dimensional (3D) arrays. $^{6}$ In addition to the metal ion connectivity and the ligand functionality, it was shown that the choice of anions, ${ }^{7}$ solvents, ${ }^{8}$ and synthetic and crystallization parameters such as temperature and pressure ${ }^{9}$ plays important roles in the formation of the final structure.

Among all metal ions, the silver ion $\mathrm{Ag}^{+}$is considered to have the lowest coordination number of two. It can therefore be considered as an ideal candidate to form 1D-coordination polymers with approximately linear, bifunctional donor ligands. Indeed, numerous examples of chain-like structures

${ }^{a}$ Department of Chemistry, University of Fribourg, Chemin du Musée 9, CH-1700 Fribourg, Switzerland. E-mail: katharina.fromm@unifr.ch; Fax: +41 263009738; Tel: +41263008732

${ }^{b}$ Department of Biomedicine, University Hospital Basel, Hebelstrasse 20, CH - 4031 Basel, Switzerland

$\dagger$ Electronic supplementary information (ESI) available: Additional figures and a table with crystallographic data for all new compounds. CCDC 765998, 849905, 849908-849912, 884807.

‡Currently at RMS-Foundation, Bettlach, Switzerland. have been reported, mainly involving N-donor ligands. They include pyrazine ${ }^{10}$ and its derivatives, ${ }^{11} 4,4^{\prime}$-bipyridine ${ }^{12}$ and longer bridged bipyridyl ligands. ${ }^{13}$ Based on its soft character, the silver ion has a quite flexible coordination sphere, and it is possible to obtain several different coordination geometries with the same metal ion and ligand. Those systems are interesting for studying the reaction conditions under which diverse different topologies can be obtained, and to study in particular the cases of polymorphism in crystal engineering. ${ }^{14}$

Silver ions are furthermore interesting targets for the construction of coordination compounds due to the different properties of this metal ion. Light stability ${ }^{15}$ and antimicrobial properties $^{16}$ are important driving forces for silver-based research. Such new compounds may indeed have great potential for applications in medicine. ${ }^{17}$

The Fromm group has a long-standing expertise in the generation of silver-based coordination polymers and has shown that such compounds are useful as antimicrobial coatings for implants. ${ }^{18-23}$ Our most basic ligand employed for the construction of silver coordination polymers is based on the flexible ethylene glycol, to which, at each end, a moiety of isonicotinic acid is fused (L1i, Scheme 1). The advantage of

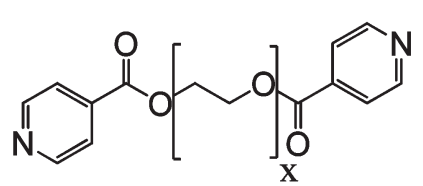

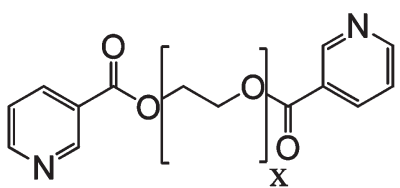

Scheme 1 Ligand families $\mathbf{L x i}$ and $\mathbf{L x n}, x=1,2,3, \ldots$ 
this kind of ligand lies in its straightforward synthesis, its flexibility as well as its biocompatibility as it is all formed of non-toxic moieties. ${ }^{18-23}$ These ligands can be further made in large quantities due to affordable starting materials.

For our studies, this ligand has been tuned in two ways: (i) the ligand length by variation of the central polyethylene oxide unit, and (ii) the position of the N-donor atom in the pyridyl unit (either 3- or 4-position), choosing either isonicotinic or nicotinic acid as a starting compound in the synthesis of the ligands. Depending on the oligomer of polyethyleneglycol as a spacer, and on the position of the N-atoms, we have established a nomenclature for our ligands (Scheme 1).

For L1i, L1n, L2i and L3i, we have already reported a series of silver coordination compounds, which form chains, metallacycles, and helices or double-helices. ${ }^{24}$ Working with neutral ligands, we have also shown the influence of counterions and solvents during the production of these silver coordination compounds, showing that polymorphs, ${ }^{22,26,27,29}$ pseudo-polymorphs (or solvates), ${ }^{26,29}$ or isomers ${ }^{25-27}$ can be obtained. We now report on the solid state structures of the new ligands, further coordination compounds of the $\mathbf{L} \mathbf{3}$ and $\mathbf{L} \mathbf{4}$ with silver salts, and their possible use in medicine.

\section{Results and discussion}

The used ligands are described with their acronym in Table 1. The synthesis of the ligands L3i, L3n, L4i and L4n is usually carried out, reacting the corresponding di-alcohol with the desired acid chlorides in a ratio of $1: 2$, always obtaining good yields.

In the following, the results of coordination of these four ligands to silver salts will be classified as a function of ligand type.

\section{Ligand L3i and its coordination compounds with silver salts}

The ligand L3i crystallizes from a THF solution in the triclinic space group $P \overline{1}$ (No. 2). The asymmetric unit contains half of the ligand, as an inversion centre is located in the geometrical middle of the C9-C9\#1 bond. The ligand adopts a Z-like shape, with the triethylene moiety almost perpendicular to the plane formed by both aromatic rings (about $17 \AA$ between $\mathrm{N}$ atoms). Both $\mathrm{N}$-atoms are pointing to opposite directions (Fig. 1). Torsion angles around $\mathrm{O}-\mathrm{C}-\mathrm{C}-\mathrm{O}$ are $\mathrm{ca} .76^{\circ}$ and $180^{\circ}$.

Reaction of $\mathbf{L 3 i}$ with $\mathrm{AgNO}_{3}$ in a 1:1 ratio leads to a stairlike chain motif of $\left[\left\{\mathrm{Ag}(\mathrm{L} 3 \mathrm{i}) \mathrm{NO}_{3}\right\}\left(\mathrm{H}_{2} \mathrm{O}\right)_{2}\right], \mathbf{1}$ (triclinic, $\left.P \overline{1}\right)$. Each silver ion is coordinated nearly linearly (N1-Ag1-N2 ca. 175 $)$ by N-atoms of two different ligands, with Ag1-N1 of 2.178(4) $\AA$, Ag1-N2 of 2.175(4) A (Fig. 2). The metal ion coordination is completed by a weakly coordinating nitrate anion (Ag1-O9 2.980(4) ̊). Opposite to the nitrate anion (angle N1-Ag1-O2 $\left.91.19^{\circ}\right)$, two O-atoms of the ethoxy part of a ligand belonging to a neighbouring chain bind with Ag1-O2 2.849(4) $\AA$ and Ag1-O3 2.944(4) $\AA$. The coordination geometry around the silver ion can thus be described as a distorted trigonal bipyramid (distances >3 Å neglected).
Table 1 Table of the ligands

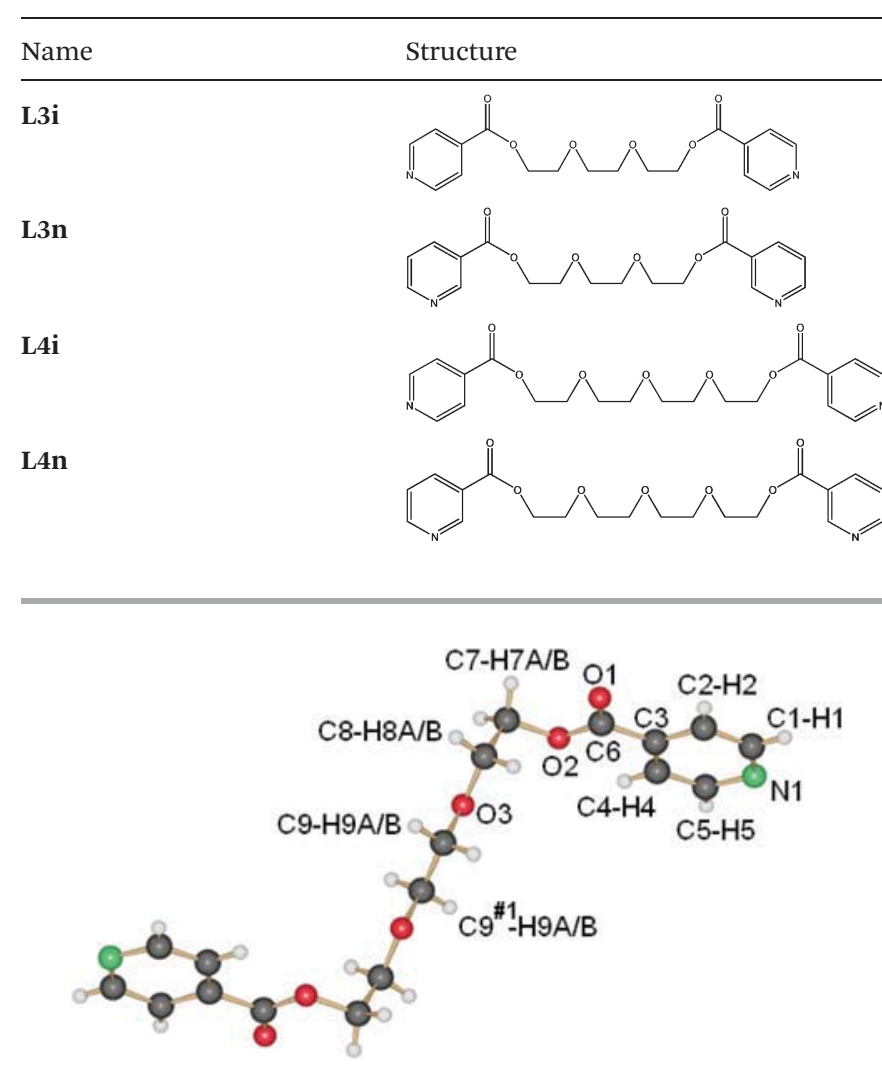

Fig. 1 Structure of ligand L3i alone; \#1: $-x,-y,-z$.

a)

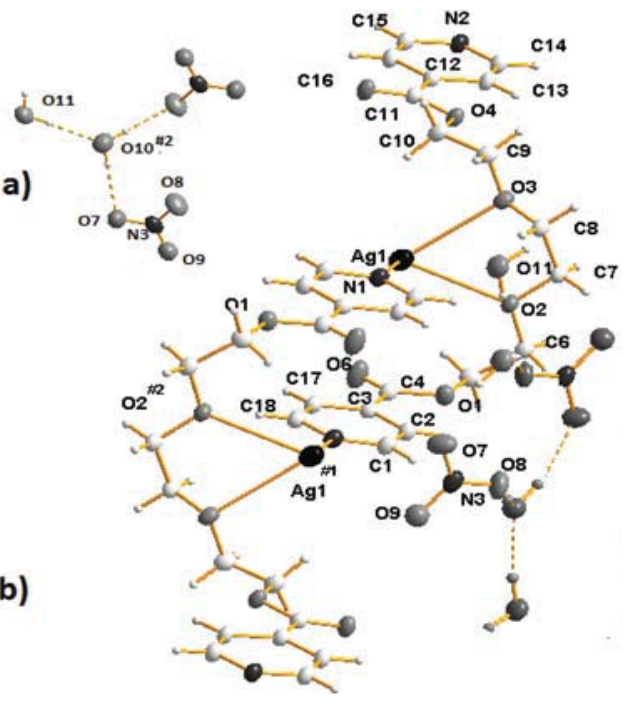

Fig. 2 Double chain arrangement of 1 ; (a) a view of the hydrogen bonding system, (b) offset of 1 shown with labelling; \#1: $-1+x, y, z$ and \#2: $1-x, 1-y$, $1-z$.

The …L3i-Ag-L3i-Ag...-chains run parallel along the (111)direction, but are offset to each other by ca. $8 \AA$ (Fig. 2), due to $\mathrm{O} 2$ and $\mathrm{O} 3$ of the polyether moiety of $\mathbf{L} 3 \mathbf{i}$ of one chain coordinating to a silver atom of a neighbouring chain. Two water molecules $\mathrm{O} 10$ and $\mathrm{O} 11$ form $\mathrm{H}$-bonds to the nitrate anions 
and build up an H-bonded system, which connects the offset chains. Thus, $\mathrm{O} 8$ of the nitrate forms H-bonds with $\mathrm{O} 10$ at $\mathrm{O} 8$ O10 2.889(6) ̊, while O10 itself is H-bonded to O11 at 2.849(3) $\AA$ A. Furthermore, $\mathrm{O} 7$ also binds to the symmetry equivalent of O10 with 2.944(3) A. The Ag-Ag distance within the same chain is around $18.92 \AA$, while the distance between $\mathrm{Ag}$-ions of two different chains is roughly $8.72 \AA$.

A compound of similar composition as $\mathbf{1}$, but with one water molecule instead of two per asymmetric unit, is obtained if THF instead of $\mathrm{MeOH}$ and water is used, yielding $[\{\mathrm{Ag}(\mathbf{L} 3 \mathbf{i})$ $\left.\left.\mathrm{NO}_{3}\right\}\left(\mathrm{H}_{2} \mathrm{O}\right)\right]$, 2. While the formula indicates simply a loss of solvent versus $\mathbf{1}$, the structure is however very different from the parallel chains in $\mathbf{1}$. Indeed, compound $\mathbf{2}$ forms a doublehelical motif and cannot be obtained by heating of $\mathbf{1}$.

The single crystals of 2 (medium quality, triclinic, $P \overline{1}$ (No. 2)) contain a ligand, a silver cation coordinated by a nitrate counterion and a water molecule per asymmetric unit. The crystallographic data allow us to obtain a partial determination of the structure. Two ligand molecules coordinate a cation via the N-atoms with Ag1-N1 and Ag1-N2 of $c a .2 .2 \AA$. The nitrate anion coordinates in a monodentate way to the silver cation with a distance of $c a$. $3.0 \AA$ (Ag1-O8). The distorted coordination geometry of the metal ion is completed by the polyether O-atoms of a second chain, leading now to a double-helical motif with distances of Ag1-O3\#2 and Ag1-O4\#2 of $c a .2 .9 \AA$, and torsion angles of $\mathrm{O} 2-\mathrm{C} 7-\mathrm{C} 8-\mathrm{O} 3\left(\mathrm{ca} .60^{\circ}\right), \mathrm{O} 3-\mathrm{C} 9-\mathrm{C} 10-\mathrm{O} 4$ (ca. 61 $1^{\circ}$ ) and $\mathrm{O} 4-\mathrm{C} 11-\mathrm{C} 12-\mathrm{O} 5\left(\mathrm{ca} .-78^{\circ}\right)$.

Double helices of 2 are aligned parallel to each other with alternating chirality. $\mathrm{Ag}-\mathrm{Ag}$ distances of $c a$. $9.2 \AA$ are observed between helices with the same chirality and of $7.7 \AA$ A between two closest silver ions for helices with opposite chirality. Weak $\pi-\pi$ interactions are present between aromatic rings of different chains within the helical motif. Other supramolecular interactions like $\mathrm{H}$-bonds exist between the nitrate ion and hydrogen atoms of the nearby pyridine ring (both coordinating

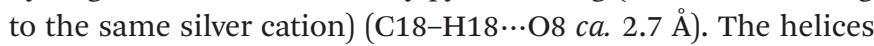
linked by $\mathrm{H}$-bonds form $2 \mathrm{D}$-sheets in the crystalline array, while water molecules occupy the empty space in between (Fig. 3).

Using $\mathrm{AgO}_{3} \mathrm{SCF}_{3}$ as starting material, the water-free compound, $\left[\mathrm{Ag}(\mathbf{L} 3 \mathbf{i}) \mathrm{O}_{3} \mathrm{SCF}_{3}\right], 3$ is obtained (monoclinic, $P 2_{1} / c$ (No. 14)). It can be described by a repetitive motif of one silver coordinated linearly $\left(c a .178^{\circ}\right)$ by two half ligands via the N-atoms with Ag-N1 of 2.159(10) $\AA$ and Ag-N2 of 2.144(10) , forming an infinite helical chain with a pitch of $c a$. $17.86 \AA$ (distance Ag1-Ag1', Fig. 4). As in 2, two chains wrap around each other, forming a double-helical motif with $\mathrm{Ag}$-O-distances to $\mathrm{O} 3$ and O4 greater than $3 \AA$. The triflate anion binds via $\mathrm{O} 7$ to the metal ion at $c a$. $2.71 \AA$, yielding a trigonal bipyramidal environment around the silver ion. Thus, the triflate anion in $\mathbf{3}$ binds stronger to the metal ion than the nitrate anion in 2 . This is compensated by longer $\mathrm{Ag}-\mathrm{O}$ distances to the polyether O-atoms in 3 compared to 2 .

Comparing compounds 2 and $\mathbf{3}$, a very similar space filling motif is found. Whereas the triflate anion of 3 is quite large compared to a nitrate anion, the latter, together with the
H-bonded water molecule, occupies about the same space as the triflate anion. Both anions act as coordinating anions in the first coordination sphere of the metal ion. We therefore suspect that this is the reason why both compounds can adopt the same structure. Two water molecules in addition to the nitrate would have been too large, and, as shown in compound 1, they then form an $\mathrm{H}$-bonded motif with the nitrate anions and a different structural motif.

Examples have already been published how the counterion, due to its multiple coordination and $\mathrm{H}$-bonding abilities, can play a decisive role in the crystal packing. ${ }^{27}$ It can act as a bridge between metal cations, ${ }^{27}$ or it can approach and connect structural motifs that otherwise would be independent. ${ }^{25}$ The $\mathrm{CF}_{3} \mathrm{SO}_{3}{ }^{-}$ion belongs to the anion type that can act in a polydentate or monodentate fashion. In $\mathbf{3}$, the oxygen atom $(\mathrm{O} 7)$ of the $\mathrm{CF}_{3} \mathrm{SO}_{3}{ }^{-}$anion not only coordinates to the metal cation, but is also involved in $\mathrm{H}$-bonding with $\mathrm{H} 1$ and

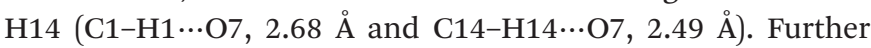
$\mathrm{H}$-bonds are formed between the carbonyl group and $\mathrm{H} 2$ of the pyridine group of a closest neighbour $(\mathrm{C} 2-\mathrm{H} 2 \cdots \mathrm{O} 1,2.56 \AA)$,
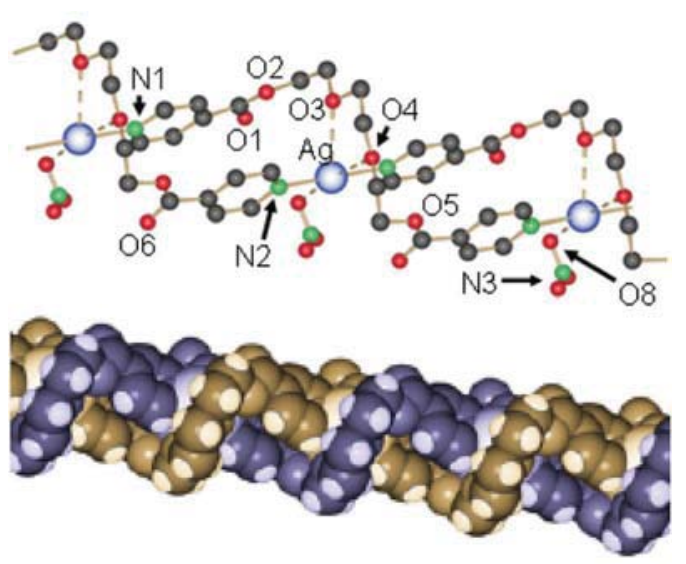

Fig. 3 Double-helix formed by compound 2, once shown without $\mathrm{H}$-atoms and with labels (top), once as a space filling model (bottom).
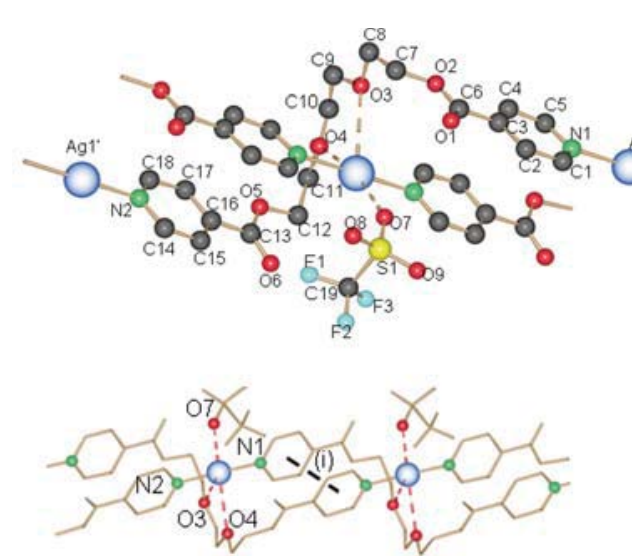

Fig. 4 Close-up of the coordination of silver in compound $\mathbf{3}$ (top), and double helix formation with $\pi-\pi$-interactions indicated by the dashed line (bottom). 


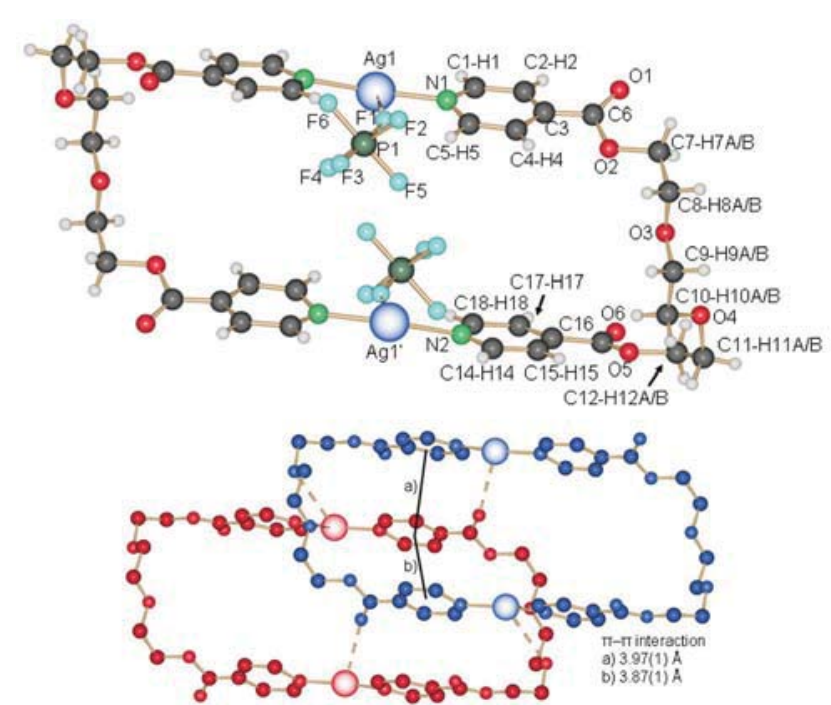

Fig. 5 Atom labelling for the ring formed in compound $\mathbf{4}$ (top) and stacking of rings (bottom)

and between $\mathrm{O} 8$ of the anion and another $\mathrm{C} 17-\mathrm{H} 17$ at $2.46 \AA$. At last one F-atom also coordinates to an $\mathrm{H}$-atom of a nearby lateral chain (C9A-H9A ‥F1, $2.91 \AA$ ).

Using a formally less coordinating anion such as $\mathrm{PF}_{6}{ }^{-}$, we were intrigued by the possible formation of new structural motifs deviating from the - helical or not - 1D motif. Indeed, compound $\left[\mathrm{Ag}(\mathbf{L} \mathbf{3 i}) \mathrm{PF}_{6}\right]_{2}, \mathbf{4}$, is obtained (triclinic, $P \overline{1}$ (No. 2)) , of which the formula already indicates a molecular motif. Indeed, a metallacyclic entity is obtained with two silver ions and two ligands forming a ring-like molecular unit, while two $\mathrm{PF}_{6}$-anions are weakly coordinating to the silver ions - one above, the other below the mean ring plane (Fig. 5). The dimensions of the metallacycle are $c a$. $6.8 \AA$ across, measured from $\mathrm{Ag} 1$ to $\mathrm{Ag} 1^{\prime}$, and $c a .18 .1 \AA$ in length (measured from C9 to $\mathrm{C}^{\prime}$ ).

The N-atoms $\mathrm{N} 1$ and $\mathrm{N} 2$ ' of two different L3i-molecules coordinate to the metal ion at 2.14(2) $\mathrm{A}$ and 2.19(2) $\AA$, respectively. The N1-Ag1-N2' angle of $161.9(9)^{\circ}$ is inclined in the direction of the triethylene glycol moiety of an offset neighbouring ring, indicating a stronger interaction with $\mathrm{O} 3$ of the latter (Ag1-O3 ca. $2.84 \AA$ ) rather than with the anion (F1-Ag1 of $c a$. $3.68 \AA$ ). The counterion has thus, if any, an extremely weak contact to the metal cation.

The pyridine rings coordinating to the same metal ion are twisted by $c a .11 .6^{\circ}$. While the carbonyl group O6-C13 remains coplanar to the neighbouring aromatic ring containing N2, the other carbonyl $\mathrm{O}$-atom $\mathrm{O} 1$ coordinates to the Ag-ion of an adjacent metallacycle (O1-Ag1 2.936 ̊). This ester group O1-C6$\mathrm{O} 2$ is twisted against the plane of the aromatic ring containing $\mathrm{N} 1$ by $c a .22 .8^{\circ}$. With $\mathrm{O} 1, \mathrm{O} 3$ and $\mathrm{O} 4$, the silver ion reaches again a trigonal bipyramidal coordination.

Two different kinds of $\mathrm{H}$-bonds are present in the structure. The O-atoms of the lateral chain coordinate to $\mathrm{H}$-atoms of the pyridine (C1-H1‥O3, ca. $2.59 \AA)$, thus bringing adjacent metallacycles closer together. More interestingly, the O-atom

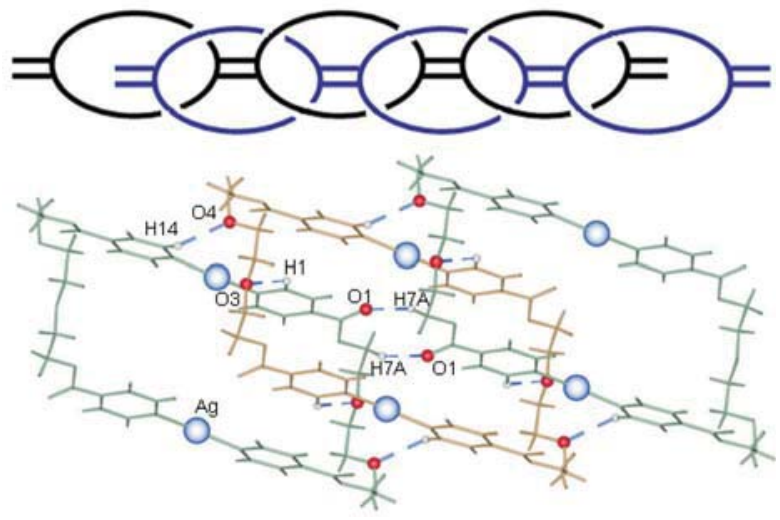

Fig. 6 Polycatenation-type of interpenetration of rings of 4 via $\mathrm{H}$-bonding motifs: schematic representation (top) and $\mathrm{H}$-bonds (bottom)

of the carbonyl group $\mathrm{O} 1$ of a first ring and the $\mathrm{H}$-atoms of the ethylene moiety of a third ring form $\mathrm{H}$-bonds passing through the cavity formed by a second metallacycle and join separated metallacycles that otherwise would not be in contact (Fig. 6). Other weak interactions like $\pi-\pi$ interactions (Fig. 5) are present and sustain the crystalline array. The $\mathrm{PF}_{6}$-anions form weak hydrogen bonds with $\mathrm{H}$-atoms of the surrounding metallacycles, acting like cement in the crystalline motif.

Compared to the 1D-structures, the ligand clearly adopts a different conformation. Indeed, two torsion angles O2-C7-C8$\mathrm{O} 3\left(\mathrm{ca} .-77^{\circ}\right)$ and $\mathrm{O} 3-\mathrm{C} 9-\mathrm{C} 10-\mathrm{O} 4\left(\mathrm{ca} .-63^{\circ}\right)$ are similar to 2 , while a third torsion angle with the same sign O4-C11-C12O5 $\left(\mathrm{ca} .-70^{\circ}\right)$ turns the molecule to the metallacycle formation and prevents the stretching of the ligand L3i to form a helical array like in 2.

In the following, we investigated the effect of the position of the N-atom within the pyridine moiety of the ligand on the structural motifs and used thus nicotinic acid instead of isonicotinic acid to prepare the ligand.

\section{Ligand L3n}

We have shown previously for shorter ligands $\mathbf{L 1}$ and $\mathbf{L} 2$ that the position of the $\mathrm{N}$-atom in the pyridine ring plays an important role in the formation of the final compounds. ${ }^{24}$ We therefore formally shifted the position of the $\mathrm{N}$-atom in $\mathbf{L 3 i}$ to the 3-position to obtain ligand L3n.

The reaction of $\mathbf{L 3 n}$ with $\mathrm{AgNO}_{3}$ yields the compound [Ag(L3n) $\mathrm{NO}_{3}$ ], 5 (monoclinic, $P 2_{1} / c$ (No. 14)) . Two ligands L3n bind to the metal ion via $\mathrm{N} 1$ and $\mathrm{N} 2$ with identical Ag-N distance of 2.182(4) $\AA$, and an N1-Ag-N2 angle of $c a$. $162^{\circ}$. L3n adopts a U-shape conformation with almost parallel pyridyl rings, with the $\mathrm{N}$-atoms pointing to opposite directions (in contrast to the Z-shape of L3i). Thus, compound 5 forms pairwise interdigitated simple helices (Fig. 7), which are more compact and less elongated than in 2 and 3 (helical pitch $c a$. $8 \AA$ in 5 compared to $c a$. 18.4 and $17.8 \AA$, in 2 and 3 , respectively). Indeed, the torsion angles around the $\mathrm{O}-\mathrm{C}-\mathrm{C}-\mathrm{O}$ moieties of 5 are $\mathrm{O} 3-\mathrm{C} 8-\mathrm{C} 7-\mathrm{O} 276.3(7)^{\circ}, \mathrm{O} 4-\mathrm{C} 10-\mathrm{C} 9-\mathrm{O} 381.5(6)^{\circ}$ and $\mathrm{O} 5-\mathrm{C} 12-\mathrm{C} 11-\mathrm{O} 478.6(6)^{\circ}$, and thus larger as compared 
a)

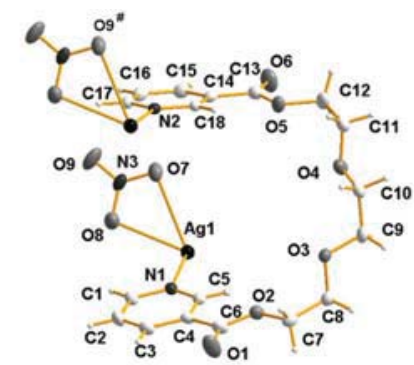

b)

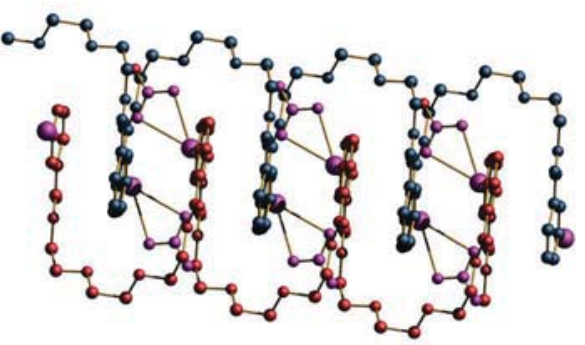

Fig. 7 (a) Labelling of compound 5, (b) parallel helices of compound 5, connected via nitrate anions connecting the chains.

with 2 and 3 . As the $\mathrm{N}$-atoms of the pyridyl units in $\mathbf{5}$ point in opposite directions, a helical arrangement rather than a ringcompound is observed. Similar as in 1, two helices of $\mathbf{5}$ are arranged pair-wise, not wrapping around each other, but in contrast to 1, they are stacked parallel to each other with short $\mathrm{Ag}-\mathrm{Ag}$ contacts of the order of $3.12 \AA$. This attractive interaction between the metal ions is also supported by the N1-Ag$\mathrm{N} 2$ of $162^{\circ}$ already mentioned above. These two silver ions are weakly and asymmetrically bridged by two symmetry related nitrate anions, above and below the metal connecting line with Ag-O8 of $c a .2 .64 \AA$, while $\mathrm{Ag}-\mathrm{O} 7$ is $>3 \AA$ A. With the metalmetal interaction, the silver ion can be considered as coordinated in a T-shape by two $\mathrm{N}$ - and one $\mathrm{O}$-atoms.

The two aromatic ring systems containing N1, respectively N2 of the same ligand are almost parallel and ca. $6.6 \AA$ away (C4-C17). This distance is ideal for intercalating another pyridine ring. Two parallel pyridyl units of two parallel chains are ca. $3.55 \AA$ (distance N1-N2) away from each other, indicating $\pi-\pi$ interactions (see also ESI $\dagger$ ).

Reacting the same ligand L3n with two equivalents of $\mathrm{AgNO}_{3}$ leads to a so far unique compound $\left[\mathrm{Ag}_{2}(\mathbf{L 3 n})\left(\mathrm{NO}_{3}\right)_{2}\right], 6$ (monoclinic, C2/c (No. 15)). Two silver ions are now coordinated by one ligand. The first silver ion Ag1 is coordinated linearly only by the N1 and N1' of two different ligands, yielding the primary motif in the form of a winding chain (N1-Ag1 2.160(2) $\AA$ ). The second silver ion Ag2 is found ligated by the four $\mathrm{O}$-atoms of the polyether moiety of the ligand $\left(\mathrm{O} 3\left(\mathrm{O}^{\prime}\right)\right.$ Ag2 of 2.522(2) Å; O2(O2')-Ag2 of 2.910(2) Å) (Fig. 8).

Similar to a crown ether motif, the four O-atoms of the polyether ligand, $\mathrm{O} 2, \mathrm{O} 3, \mathrm{O}^{\prime}$ and $\mathrm{O}^{\prime}$ ', lie approximately within a plane, giving rise to $\mathrm{O}-\mathrm{C}-\mathrm{C}-\mathrm{O}$ torsion angles of $c a$. $74^{\circ}$. Thus, the ligand $\mathbf{L} 3 \mathbf{n}$ is so tightly wrapped around Ag2 that the $\mathrm{N}$-atoms of the same ligand are only $c a$. $3.5 \AA$ away from each other, allowing no intercalation of a second ligand in the

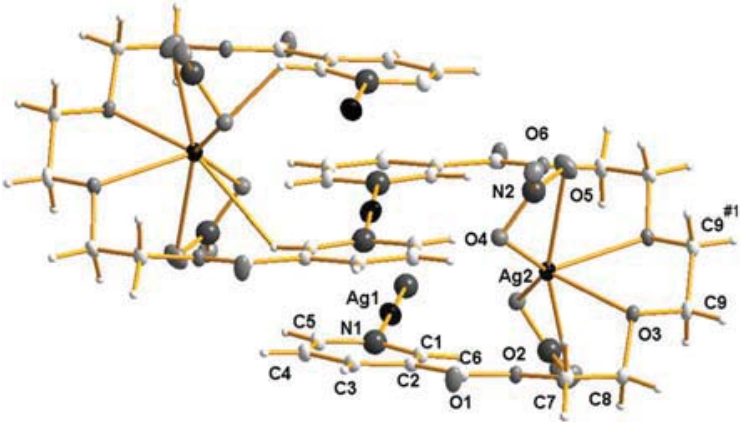

Fig. 8 Helical silver coordination polymer $\mathbf{6},\left[\mathrm{Ag}_{2}(\mathbf{L} \mathbf{3 n})\left(\mathrm{NO}_{3}\right)_{2}\right]$ with labelling of the asymmetric unit. (ellipsoids are at $40 \%$ probability level, $\# 1-x, y, 1.5-z$ ).

helical groove as in $\mathbf{5}$. The coordination sphere of Ag2 is completed by two nitrate anions formed around N2 and its symmetry equivalent, binding via $\mathrm{O} 4$ and $\mathrm{O} 5$, at $\mathrm{Ag} 2-\mathrm{O} 4$ 2.388(2) $\AA$ and Ag2-O5 with 2.689(2) $\AA$, resulting in a distorted square bipyramid around the metal ion (considering the nitrate $\mathrm{O}$ atoms as apical ligands). Although $\mathrm{Ag} 2$ seems to have an "open side" from which no ligands coordinate, the space filling model shows that the metal ion is not accessible (ESI ${ }^{\dagger}$ 2, space filled projection).

As the chains formed by the ligand molecules and Ag1 arrange such that the ligand winds alternatingly to the left and to the right, the $\mathrm{Ag}\left(\mathrm{NO}_{3}\right)_{2}$-units around $\mathrm{Ag} 2$ of every second ligand come to stack offset on top of each other with short distances between the nitrate anions of $\mathrm{O}^{-}-\mathrm{O6}^{\prime}<3 \AA$. Repulsion between these anions is however diminished by $\mathrm{O} 6-\mathrm{H}$ inter-

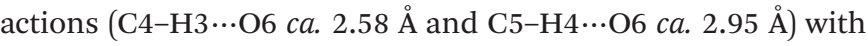
adjacent pyridyl entities.

Our interest in preparing mixed metal compounds with multitopic ligands ${ }^{32 a}$ let us to investigate the even longer ligands L4i and L4n.

\section{Ligands L4i and L4n}

The ligands L4i and L4n were crystallized and their structures are given in Fig. 9. L4i crystallizes in the triclinic space group $P \overline{1}$ (No. 2), while L4n is orthorhombic with space group F2dd (No.43). ${ }^{33 a}$

L4i adopts a U-shape while L4n, like L3i, has a Z-shape. This is due to the differences in torsion angles around the ethyl groups. For L4i, the two middle $\mathrm{O}-\mathrm{C}-\mathrm{C}-\mathrm{O}$ angles are nearly perfectly oriented anti with $c a .176^{\circ}$, while the two outer $\mathrm{O}-\mathrm{C}-\mathrm{C}-\mathrm{O}$ angles are almost perfectly gauche with $c a .65^{\circ}$. Although L4i adopts a U-shape, the $\mathrm{N}$-atoms are oriented such that they point to different directions (Fig. 9), with a distance between the two N-atoms of $12.6 \AA$. For L4n, the structure is more elongated with a total length of $c a$. 15.6 $\AA$ measured between both $\mathrm{N}$-atoms. The torsion angles in L4n are much nearer the all-gauche conformation, with $c a .65^{\circ}$ and $75^{\circ}$. We have observed such a general trend of alternating $\mathrm{Z}$ - and U-shapes as a function of even and uneven numbers of ethylene oxide groups on one hand, and the position of the N-atom on the other. Thus, L1i, L2n, ${ }^{25-27}$ L3i and L4n adopt a Z-shape, 

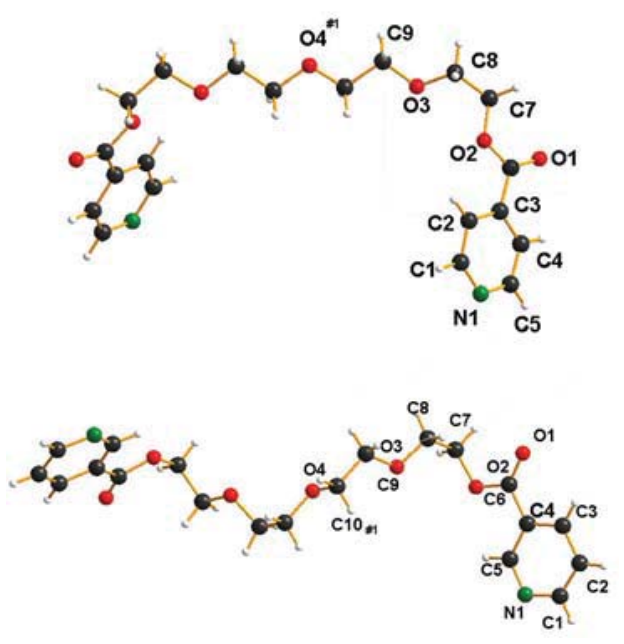

Fig. 9 Ligand L4i (top) with \#1: $-x, 1-y, 1-z$ and $\mathbf{L} \mathbf{n}$ (bottom) with \#1: $x_{1}-y_{1}-z$.

while L1n, L2i, ${ }^{25-27}$ and L4i (and presumably also L3n) adopt the U-shape. As the energy of rotation around a $\mathrm{C}-\mathrm{C}$-bond is weak, we do not expect large differences in the energies of the different conformers. However, packing effects such as $\mathrm{H}_{-}$ bonds and segregation along hydrophilic and hydrophobic parts of the chains seem to play roles. For example, the nicotinic acid moiety is asymmetric and thus likely more polar than the isonicotinic unit. Indeed, the isonicotinic acid moiety of L4i interacts with another isonicotinic acid unit of another ligand via short contacts between the $\mathrm{N}$-atom and a $\mathrm{C}-\mathrm{H}$ group of a pyridine ring ( $(\mathrm{N} 1 \cdots \mathrm{H} 2 \quad 2.77 \AA)$ and forms edge-to-face interactions between two aromatic rings (H1...C5 $2.78 \AA$ ). For $\mathbf{L 4 n}$, the $\mathrm{N}$-atom of the pyridyl group interacts more strongly with a $\mathrm{CH}_{2}$-group of the polyether chain of a neighbouring

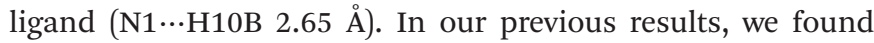
out that $\mathbf{L} 1$ and $\mathbf{L} 2$ seemed to maintain their preferred solid state "shape" upon coordination to silver. ${ }^{17-29}$ If this is also the case for the $\mathbf{L 4}$ ligand family will be described in the following.

Upon reaction of $\mathbf{L 4 i}$ with $\mathrm{AgO}_{3} \mathrm{SCF}_{3}$, the compound [Ag(L4i) $\left.\mathrm{O}_{3} \mathrm{SCF}_{3}\right]_{2}, 7$, is obtained (triclinic, $P \overline{1}$ (No. 2)). The asymmetric unit of $\mathbf{7}$ is composed of one ligand $\mathbf{L 4 i}$, one silver ion and one anion. Two silver ions and two ligands form an almost rectangular metallacycle as the basic building block of compound 7 (Fig. 10). The metal ion is coordinated by N1 and N2 of two different ligands at 2.179(9), respectively 2.169(9) $\AA$, forming an angle of $150.1(3)^{\circ}$. This deviation from linearity already indicates interactions with $\mathrm{O} 3, \mathrm{O} 4$ and $\mathrm{O} 5$ of a ligand belonging to a neighbouring metallacycle, coordinating to Ag1 with $2.774(7), 2.561(8)$ and 2.736(7) $\AA$, respectively. This gives the silver ion a T-shaped coordination with additional two donors in the equatorial plane similar to a fan. On the opposite side with respect to these O-donor atoms, the triflate anion is found, but not directly coordinating with a distance O10-Ag1 >4 A. O8 of the anion forms H-bonds to a neighbour stack of rings $(\mathrm{O} 8 \cdots \mathrm{H} 3-\mathrm{C} 5 \mathrm{ca} \cdot 2.71 \AA$ and $\mathrm{O} 8 \cdots \mathrm{H} 24-\mathrm{C} 20 \mathrm{ca}$.

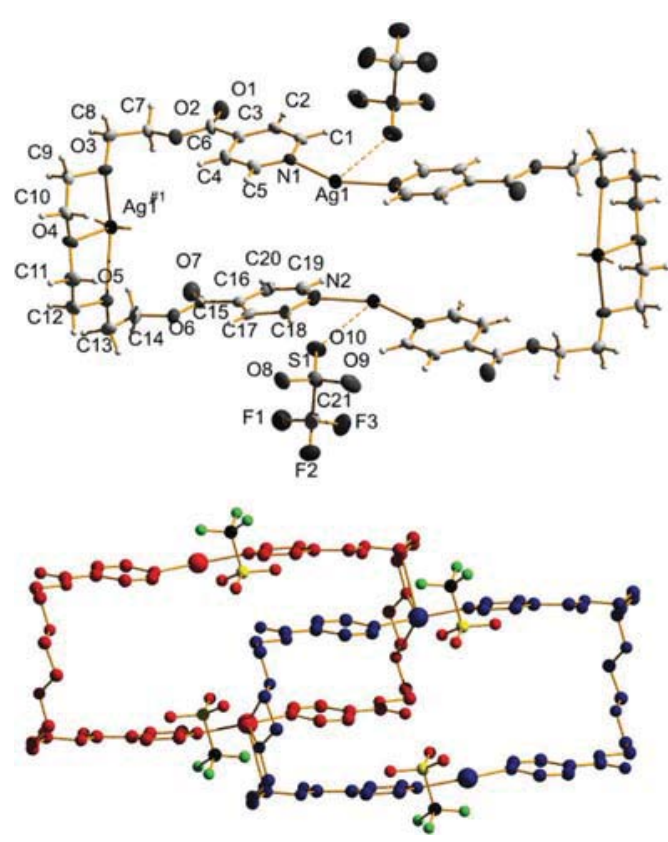

Fig. 10 Metallacycle of $\mathbf{7}$ with labelling (top) and stacking of the rings, $\mathrm{H}$-atoms omitted for clarity (bottom).

$2.51 \AA)$. Thus, these metallacycles are stacked stair-wise on top of each other (Fig. 10), similar as in compound 4, but with rings of larger dimension ( $c a$. 7.3 $\AA$ across from metal to metal ion, and $20.1 \AA$ long from C11 to its symmetry equivalent). As in $\mathbf{4}$, an H-bonding system exists between every first and third ring, based on a short contact between $\mathrm{O} 7$ and $\mathrm{H} 19$ (O7...H19C14 ca. $2.54 \AA$ ), and pointing through the cavity of the second ring. Torsion angles around the $\mathrm{O}-\mathrm{C}-\mathrm{C}-\mathrm{O}$ are $66^{\circ}$ on average. Thus, the general shape of the ligand (U-shape) is maintained to form the ring systems, but the middle part of the ligand is now nearly in gauche conformation, probably due to the coordination of the involved O-atoms to a silver ion of a neighbouring ring.

Exchanging the position of the $\mathrm{N}$-atom and using $\mathbf{L 4 n}$ with $\mathrm{AgNO}_{3}$ lead to the compound $\left[\mathrm{Ag}(\mathbf{L} 4 \mathbf{n}) \mathrm{NO}_{3}\left(\mathrm{CH}_{3} \mathrm{OH}\right)\right]_{2}, \mathbf{8}$ (monoclinic, $P 2_{1} / c$ (No 14)). Again, metallacycles based on two silver ions and two ligands are obtained (Fig. 11). Within a ring, the silver ions are coordinated by $\mathrm{N} 1$ and $\mathrm{N} 2$ of two different ligands with 2.175(7) and 2.164(2) A, respectively, forming a nearly linear angle N1-Ag1-N2 of almost $176^{\circ}$, thus contrasting 7 . Two symmetry equivalent nitrate anions bridge the two silver ions of the same metallacycle via O8 (O8-Ag ca. $2.76 \AA$ on average) while 09 binds only to one silver ion at $c a$. $2.83 \AA$ as well, leading thus to a T-shaped coordination sphere for the silver ion with two additional O-atoms in a fan-like arrangement as in 7. O9 forms also weak interactions with $\mathrm{H} 4$, $\mathrm{H} 10$ and $\mathrm{H} 22$ of the surrounding pyridyl units, and to H21A of the methyl group of the methanol molecule. The oxygen atom $\mathrm{O} 10$ of the nitrate forms also an H-bond with $\mathrm{O} 11$ of the methanol.

Including the methanol O-atoms in the coordination sphere of the metal ions would lead to a pentagonal 


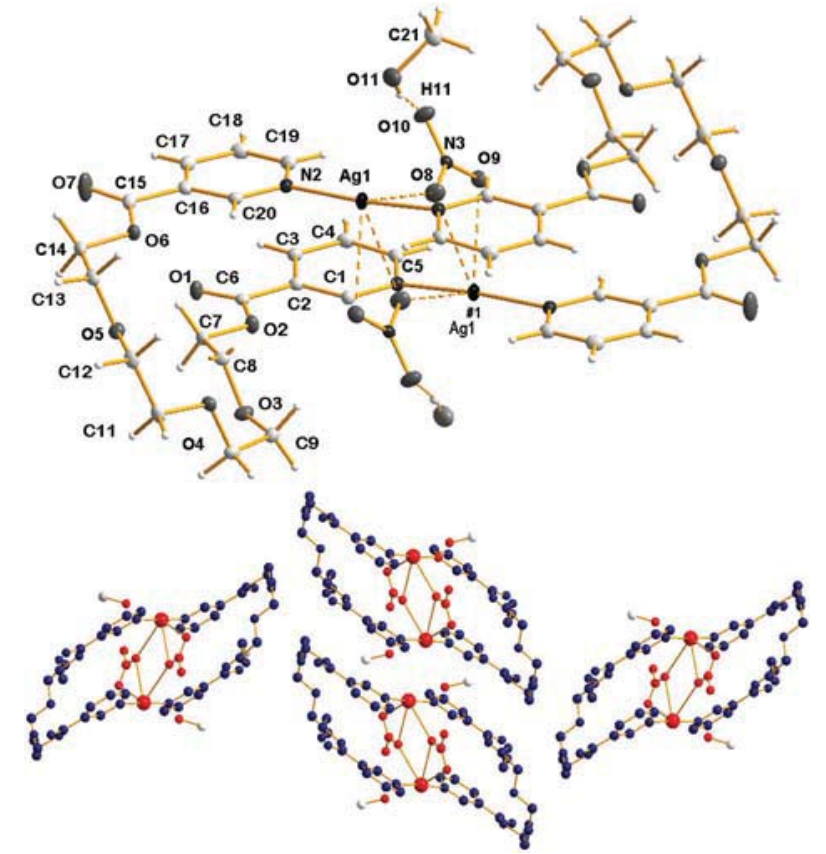

Fig. 11 Metallacycle of compound 8 with numbering (top) and packing of rings, $\mathrm{H}$ atoms omitted for clarity (bottom).

bipyramidal environment, however, the $\mathrm{Ag}-\mathrm{O} 11$ distance is greater than $3 \AA$. We have reported smaller metallacycles with L2i, which are, depending on the anion, either bridged within the same ring (intra-ring), between two neighbouring rings (inter-ring) or via both ways. ${ }^{25,26}$ In compound 8, the nitrate bridges internally, while the methanol molecule acts as a weak connector between the rings.

In contrast to 7, the polyether moieties of the ligand L4n do not coordinate to metal ions of neighbouring metallacycles. Thus, the torsion angles around the $\mathrm{O}-\mathrm{C}-\mathrm{C}-\mathrm{O}$ groups of $\mathbf{L 4 n}$ range from 64 to $74^{\circ}$ and are thus similar as in the free ligand. The rings of $\mathbf{8}$ are so twisted that the mean plane through the $\mathrm{O}$-atoms of the polyether part forms an angle of $c a .70^{\circ}$ to the mean plane containing the two silver ions and four $\mathrm{N}$-atoms. Due to this distortion, stacking cannot occur as in 7. Instead, the ligand is so twisted that the two aromatic rings of a ligand are parallel but offset, so that $\mathrm{C} 2$ and C19 come to lie on top of each other with the shortest contact between the rings of about 3.6 $\AA$ (Ag …Ag of $c a .4 .8$ and $\mathrm{C} 11 \cdots \mathrm{C} 11^{\prime}$ of $c a .17 .3 \AA$ ).

Furthermore, two pyridyl moieties, one with N1, the other with N2, of two adjacent neighbouring rings, have offset close contacts, with $\mathrm{N} 1-\mathrm{C} 20$ being the shortest with $c a$. $3.3 \AA$ A. The metallacycles are thus arranged parallel to each other.

The polyether chain of $\mathbf{L A n}$ is in principle large enough to accommodate a second metal ion, as shown for compound 6 where already the smaller ligand $\mathbf{L} 3 \mathbf{n}$ is able to coordinate to two metal ions. Indeed, we tested this possibility by reaction of the same ligand with two equivalents of silver nitrate, yielding compound $\left[\mathrm{Ag}_{2}(\mathbf{L} 4 \mathbf{n})\left(\mathrm{NO}_{3}\right)_{2}\right]_{2}, 9$ (monoclinic, $P 2_{1} / c$ ) with one ligand, two silver and two nitrate ions per asymmetric unit.
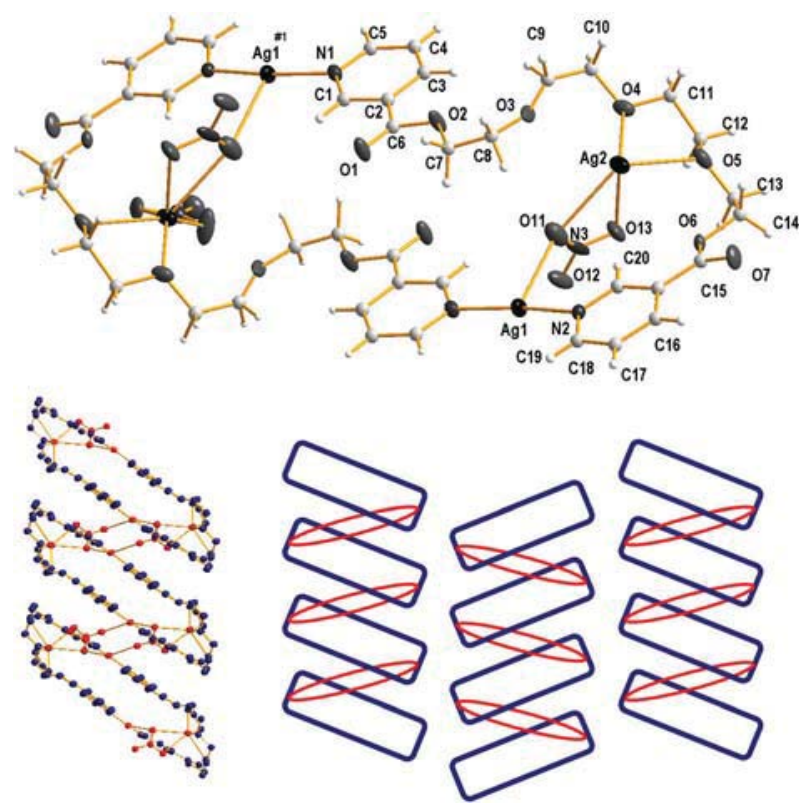

Fig. 12 Metallacycle of $\mathbf{9}$ with numbering (top) and linking of two metallacycles via nitrate and aromatic stacking (bottom). Blue indicates the ligands of the metallacycles $(\mathbf{L} \mathbf{n n A g})_{2}$, red indicates the $\left(\mathrm{AgNO}_{3}\right)_{2}$-motif which connects the rings together. Ellipsoids are at $40 \%$ probability level, $\# 1-x, 1-y,-z$.

Two ligands L4n form with two silver ions, Ag1 and its symmetry equivalent, again a metallacycle (Ag1-N with 2.139(9) for $\mathrm{N} 1$ and 2.164(9) $\AA$ for N2, N1-Ag1-N2 168.6(4) $)^{\circ}$, which is now much flatter than the one in 8. The ligand L4n of compound $\mathbf{9}$ features torsion angles of $\mathrm{ca} .-14^{\circ}$ (from $\mathrm{O} 2$ to $\mathrm{O} 3$ ), $-67^{\circ}$ (from $\mathrm{O} 3$ to $\mathrm{O} 4$ ), a third of $c a .67^{\circ}$ (O4 to $\mathrm{O} 5$ ) and the last at $c a$. $-80^{\circ}$ (O5 to $\left.\mathrm{O} 6\right)$. This is clearly due to the coordination of $\mathrm{O} 4$ and $\mathrm{O} 5$ to the second silver ion Ag2 with 2.430(8) and 2.495(9) $\AA$, respectively. O6 is only very weakly connected to Ag2 with $>3.3 \AA$ A. Similar as in $\mathbf{6}, \mathrm{Ag} 2$ is coordinated by two nitrate anions around $\mathrm{N} 3$ and N4 with $\mathrm{Ag} 2-\mathrm{O}$ distances between

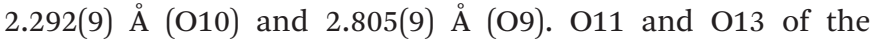
nitrate around N3 also connect to Ag2 with 2.698(9) respectively 2.564(9) $\AA$. O11 connects to Ag1 of the same ring with a distance of 2.637(9) $\AA$. O12 of the nitrate anion around N3 connects with 2.842(7) A to a silver ion of a neighbouring metallacycle. Vice versa, the symmetry equivalent $\mathrm{O} 12$ of this neighbouring ring binds also to Ag1 of the first ring. Ag1 has thus a T-shaped coordination sphere where only the shortest contacts are taken into account, while $\mathrm{Ag} 2$ is best described as having a distorted square pyramidal environment. The aromatic rings of adjacent metallacycles are in parallel planes, but offset, with the shortest contact between $\mathrm{C} 1$ of one pyridyl unit and $\mathrm{N} 2$ of the other (ca. $3.3 \AA$ ). Hereby, an inter-ring connectivity via $\mathrm{O} 12$ and its symmetry equivalent, as well as via aromatic stacking is maintained, overall leading to a 1D stack of rings (Fig. 12 bottom). These stacks of rings are oriented with alternating inclination, leading thus to a fishbone motif (Fig. 12) (see also ESI $\dagger$ 3). The dimension of the ring in 9 is 19.6 ̊ in length, measured from O6 to O6', but only $3.3 \AA$ in width, measured between $\mathrm{O} 1$ and $\mathrm{O}^{2}$. 


\section{Comparison}

\section{Role of coordination number}

These nine new coordination compounds show different structural motifs related with the (nearly) linear coordination of silver ions by the $\mathrm{N}$-donor atoms. For a ligand to silver ratio of $1: 1$, chains can occur in different variations, e.g. as simple offset chains with $\mathbf{L} \mathbf{3} \mathbf{i}$, as pairs of helical chains with $\mathbf{L} \mathbf{3} \mathbf{n}$ or as double helices with $\mathbf{L 3} \mathbf{i}$. Among all reactions tested with $\mathbf{L} 3 \mathbf{i}$ or L3n, only one case of a metallacyclic compound was observed with a non-coordinating anion and L3i. For the same ratio, both ligands L4i and L4n seem to form preferentially metallacycles, no double-helices, helices or chains were observed so far. We have observed such a similar behaviour with the shorter homologues, where L1i or L1n most often yields 1D coordination polymers, ${ }^{22,27,28}$ while with L2i and L2n, 0-D ring-structures are more frequently observed. ${ }^{26}$ For the ligand to metal ratio $1: 2$, L3n gives a chain-like compound, while L4n and L4i prefer to yield rings. Surprisingly, the coordination of silver by O-atoms is not limited to the linear arrangement. Thus, in compound 6 (with a ligand to metal ratio 1 to 2) we observe for the first time in our series of silver coordination compounds with Lxi and Lxn that silver can be coordinated by solely O-atoms of the polyether chain and of the counterion.

\section{Role of the ligand length}

A first conclusion from previous results ${ }^{17-30}$ might be drawn that Lxi and Lxn with $x$ being even numbers of ethylene oxide groups lead more frequently to metallacyclic compounds whereas uneven numbers rather lead to chain-like compounds. However, the longer the ligands get, the more conformational possibilities we observe, as can be seen in the different torsion angles about the $\mathrm{O}-\mathrm{C}-\mathrm{C}-\mathrm{O}-$ moieties.

For ligand L1i, many 1D structures are known, some of them are true polymorphs, ${ }^{26,29}$ others are isomers ${ }^{25-27}$ or solvates (pseudo-polymorphs). ${ }^{26}$ For L2i however, we have reported that both $1 \mathrm{D}$ and $0 \mathrm{D}$-structures can occur with a ring and a helix occurring as polymorphs from the same reaction. ${ }^{30}$

Hosseini et al. have also reported a double-helix with the longer ligand L6i, showing that the trend to form alternating chains and rings with uneven and pair numbers of ethylene oxide units is not strict. ${ }^{31 a}$ They also described a double helix formation when L4n or L6n was reacted with silver salts containing rather non-coordinating anions such as $\mathrm{AgBF}_{4}$ or $\mathrm{AgPF}_{6} \cdot{ }^{31 b}$

\section{Role of solvent}

Upon complexation of $\mathbf{L 3} \mathbf{i}$ to silver, the solvent seems to play an important role. Reactions in THF seem to yield preferentially chains (linear of helical chains), while a ring compound is obtained from acetonitrile. From a thermodynamic point of view, ring compounds should be preferred over chain compounds due to entropy. However, chains are frequently observed, also because of their insolubility, once they are formed. THF is not a good solvent for such 1D compounds as it does not coordinate well to silver ions. The kinetic product can thus be obtained. Acetonitrile however is an N-donor ligand and thus competitive versus L3i (and the other ligands as well), hence the thermodynamic products, the ring compounds, are favoured. This seems to be confirmed when $\mathrm{MeOH}$ is used during the reaction, which leads again to $1 \mathrm{D}$ compounds, independently from the ligand to metal ratio. $\mathrm{MeOH}$ is however a better donor than THF, as also metallacycles can be obtained with L4i and L4n from $\mathrm{MeOH}$ as solvent. For the metallacycle formed with L4i the dimensions of the ring allow intercalated, offset stacking of the rings. For L4n the metallacycle is much more compressed, not allowing offset stacking. Both L4n compounds have rings packed in a fishbone motif.

\section{Role of the anion}

For compounds 2,3 and $\mathbf{4}$, there seems to be a trend that strongly coordination anions lead to double helices, as the ligand L3i alone is not able to complete the coordination sphere of the silver ion. While nitrate seems always to interact strongly with the silver ion, other anions, like triflate or $\mathrm{PF}_{6}{ }^{-}$, seem to be less interacting, as it was also already observed in previous compounds with shorter ligands. ${ }^{17,26-30}$ In compound $\mathbf{9}$, the nitrate anions connect the silver ions of two different metallacycles into an inorganic silver nitrate moiety. Such an asymmetric coordination of nitrate to silver ions was hitherto unknown to the best of our knowledge. Also, only the Lxn ligands gave us 1:2 adducts with silver salts, while the Lxi ligands gave so far only $1: 1$ compounds, even if the silver salt was added in excess.

\section{Antimicrobial properties versus biocompatibility}

Our silver compounds with L1i and L1n have shown excellent antimicrobial properties. ${ }^{18,20}$ These properties are based on the solubility and thus silver ion release into the environment. The more silver ions are released, the stronger the effect. On the other hand, if silver compounds want to find applications in the medical sector, they also have to be biocompatible, which is only guaranteed if the silver ion concentration remains below a cytotoxic threshold. ${ }^{18-23}$ Thus, the solubility of silver compounds is one of the main issues in this respect. While L1i and L1n are not significantly soluble in water, the solubility of the ligands increases with the chain length of the spacer. The solubility of the ligand strongly influences the solubility of the silver ion when linked to these ligands compared to pure $\mathrm{AgNO}_{3}$ (solubility of $1.22 \mathrm{~kg} \mathrm{l}^{-1}$ at $0{ }^{\circ} \mathrm{C}$ ). For instance, silver coordination compounds based on $\mathbf{L 1 i}$ and $\mathrm{AgNO}_{3}$ release only $c a$. $5-10$ ppm of silver ions into water. ${ }^{18,20}$ We have shown that silver coordination compounds based on L2x are more soluble than the ones with L1x and have a stronger antimicrobial effect. ${ }^{20,23}$ On the other hand, coatings based on L2x and silver nitrate show, at the same concentration coating as L1x-compounds, a higher cytotoxicity towards 3T3 fibroblast cells. L3x and $\mathbf{L 4 x}$ have even longer polyether chains and are better soluble than the 
Table 2 MIC and MBC values of silver complexes

\begin{tabular}{lll}
\hline Compound & $\begin{array}{l}\text { MIC }(\mu \mathrm{g} / \mathrm{mL} \\
(\text { and } \mathrm{mmol} \mathrm{Ag} / \mathrm{mL}))\end{array}$ & $\begin{array}{l}\text { MBC }(\mu \mathrm{g} / \mathrm{mL} \\
(\text { and } \mathrm{mmol} \mathrm{Ag} / \mathrm{mL}))\end{array}$ \\
\hline $\mathbf{1}$ & $3.90(6.90)$ & $7.81(13.82)$ \\
$\mathbf{5}$ & $7.81(14.76)$ & $15.63(29.54)$ \\
$\mathbf{6}$ & $7.81(22.38)$ & $15.63(44.79)$ \\
7 & $7.81(11.83)$ & $15.63(23.68)$ \\
$\mathbf{9}$ & $3.90(10.51)$ & $15.63(42.13)$ \\
\hline
\end{tabular}

shorter ligands. Furthermore, the molecular, ringbased compounds should again be in general more soluble than the coordination polymers. Thus, we expect good antimicrobial properties, yet poor biocompatibilities for our compounds 1-9. The four ligands tested alone did not show any antimicrobial effect or cytotoxicity (data not shown).

We determined the MIC (minimal inhibitory concentration) and $\mathrm{MBC}$ (minimal bactericidal concentration) for a chosen number of our compounds with a $1-5 \times 10^{5} \mathrm{CFU} \mathrm{mL}^{-1}$ inoculum of $S$. epidermidis 1457 . The results are given in Table 2.

The MIC and MBC for all compounds are similar with a trend of a stronger effect for compounds 1 and 9. The inhibition zones obtained from agar diffusion tests for compounds 5, 6, 7 and 9 with concentrations between 0.1 and $5 \mathrm{mg} \mathrm{mL}^{-1}$ are each ca. $15 \mathrm{~mm}$ in diameter for inoculum of $10^{7} \mathrm{CFU} \mathrm{mL} \mathrm{m}^{-1}$ of $S$. epidermidis 1457 , ca. $20 \mathrm{~mm}$ with $10^{6} \mathrm{CFU} \mathrm{mL}^{-1}$ and $c a$. $25 \mathrm{~mm}$ for $10^{4} \mathrm{CFU} \mathrm{mL} \mathrm{m}^{-1}$ inoculum. All compounds, except $\mathbf{1}$, start to be active against $S$. epidermidis 1457 at ca. $50 \mu \mathrm{g} \mathrm{mL} \mathrm{m}^{-1}$. Compound 1 at a concentration of $10 \mu \mathrm{g} \mathrm{mL}^{-1}$ shows already an inhibition zone of $10 \mathrm{~mm}$ for $10^{4} \mathrm{CFU} \mathrm{mL} \mathrm{m}^{-1}$ S. epidermidis 1457 and $8 \mathrm{~mm}$ for $10^{6} \mathrm{CFU} \mathrm{mL}^{-1}$, while it is not active against

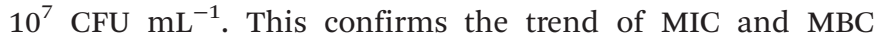
measurements that compound $\mathbf{1}$ has the best antimicrobial activity among the tested samples. This effect holds still true when converting the mass into molar amounts of silver ions exposed. Compound $\mathbf{1}$ is based on the least soluble (in polar solvent water) ligand L3i. A slow and continuous release of silver is expected and should kill bacteria efficiently over longer times. Compound $\mathbf{9}$ on the other hand releases for the same mass twice as many silver ions and appears thus strong in terms of mass, but it is not so efficient in terms of silver ion release.
The in vitro biocompatibility of a number of compounds was assessed by a MTT assay, measuring the optical density of cell growth cultures using mouse fibroblast as model cells. The highest concentration at which the optical density increases as desired within a period of four days is $10 \mu \mathrm{g} \mathrm{mL}$ for compounds $2\left(18.28 \mathrm{mmol} \mathrm{Ag} \mathrm{mL} \mathrm{m}^{-1}\right), 5$ (18.90 $\mathrm{mmol} \mathrm{Ag}$ $\left.\mathrm{mL}^{-1}\right)$ and $9\left(26.95 \mathrm{mmol} \mathrm{Ag} \mathrm{mL}^{-1}\right)$, while compounds 1

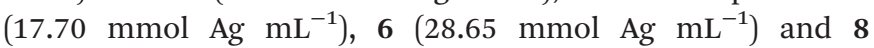
(16.53 mmol $\mathrm{Ag} \mathrm{mL}^{-1}$ ) are cytotoxic at this concentration, showing no cell growth whatsoever. Thus, all compounds show no reasonable therapeutic window for use within coatings on medical devices to be utilized in the human body.

\section{Conclusions}

In conclusion, we present three new ligands derived from oligomers of polyethylene glycol, substituted at both ends with nicotinic or isonicotinic acid moieties. Almost no metal complexes are known for these ligands, ${ }^{32}$ and only one silver compound with L4n was known before our study, ${ }^{31 b}$ such that we therefore contribute nine new coordination compounds with silver. Upon coordination to silver salts in organic solvents, we have observed the structure types as recollected in Table 3. The structures can be categorized on the one hand into $1 \mathrm{D}$ coordination polymer motifs, featuring closely packed linear chains, helical chains as well as double helices. On the other hand, metallacycles were observed, representing the class of $0 \mathrm{D}$ compounds. No interpenetrated or catenated compounds were observed, but we cannot exclude that they can exist.

While general trends can be identified, the role of the reaction solvent and the co-crystallizing solvent as well as the role of the anion remains difficult to predict, but may play a crucial role in the structure assembly.

The ligands seem to adopt preferential conformations in the solid states, which are roughly maintained upon coordination to silver. The longer the ligands, the more possibilities of different conformations can in principle be expected, especially when changes in anions and solvents occur as well. For the first time in our series of silver coordination compounds, we observed (i) a $1: 2$ ratio of ligand to silver salt in the final coordination compound, and (ii)

Table 3 Classification of silver complexes in family of networks

\begin{tabular}{|c|c|c|c|c|}
\hline \multirow[b]{2}{*}{ Linear chain } & \multicolumn{2}{|l|}{ Metallacycle } & \multicolumn{2}{|l|}{ Helix } \\
\hline & Regular & Distorted & Single & Double \\
\hline 7 & $\rightleftarrows$ & & 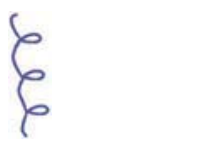 & 6 \\
\hline $\begin{array}{l}\mathbf{1}\left[\left\{\mathrm{Ag}(\mathrm{L} 3 \mathrm{i}) \mathrm{NO}_{3}\right\}^{*}\left(\mathrm{H}_{2} \mathrm{O}\right)_{2}\right] \\
\left.\mathbf{6}\left[\mathrm{Ag}_{2}(\mathrm{~L} 3 \mathrm{n}) \mathrm{NO}_{3}\right)_{2}\right]\end{array}$ & $\begin{array}{l}4\left[\mathrm{Ag}(\mathrm{L} 3 \mathrm{i}) \mathrm{PF}_{6}\right]_{2} \\
\left.7[\mathrm{Ag}(\mathrm{L} 4 \mathrm{i})] \mathrm{O}_{3} \mathrm{SCF}_{3}\right]_{2}\end{array}$ & $\begin{array}{l}\left.\mathbf{8}\left[\mathrm{Ag}(\mathrm{L} 4 \mathrm{n}) \mathrm{NO}_{3}\left(\mathrm{CH}_{3} \mathrm{OH}\right)\right]_{2}\right\} \\
\mathbf{9}\left\{\left[\mathrm{Ag}_{2}(\mathrm{~L} 4 \mathrm{n})\left(\mathrm{NO}_{3}\right)_{2}\right]_{2}\right.\end{array}$ & $5\left[\mathrm{Ag}(\mathrm{L} 3 \mathrm{n}) \mathrm{NO}_{3}\right]$ & $\begin{array}{l}2\left\{\left[\mathrm{Ag}(\mathrm{L} 3 \mathrm{i}) \mathrm{NO}_{3}\right\}\left(\mathrm{H}_{2} \mathrm{O}\right)\right] \\
3\left[\mathrm{Ag}(\mathrm{L} 3 \mathrm{i}) \mathrm{O}_{3} \mathrm{SCF}_{3}\right]\end{array}$ \\
\hline
\end{tabular}




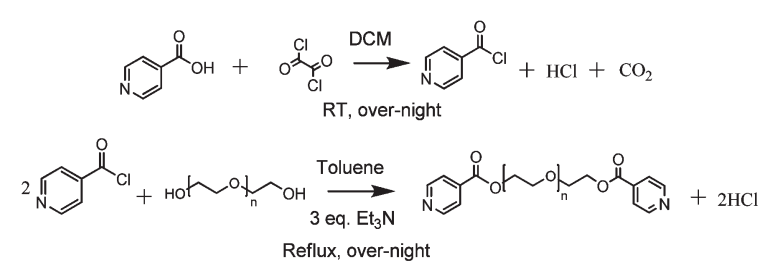

Scheme 2 The two step reaction for the synthesis of the ligands.

that silver could be coordinated only by O-atoms of the polyether chains and of the anions, but without connection to $\mathrm{N}$-donors.

While all the silver coordination compounds described here, especially $\mathbf{1}$ and $\mathbf{9}$, exhibit strong antimicrobial properties, the therapeutic window is too small, respectively nonexisting for uses in which biocompatibility of the compounds is required.

We expect such multitopic ligands with medium and long polyether chains, featuring $\mathrm{O}-$ as well as N-donor atoms as potentially interesting for the preparation of mixed metal compounds as precursors for oxide materials and are currently working in this area. ${ }^{33}$

\section{Experimental}

All starting products are commercially available and were purchased from Acros Organics and Sigma Aldrich.

\section{Chromatography purification and analysis}

Analytical thin sheet chromatography (TLC) was performed with Merck silica gel 60 F-254 plates. Column chromatography was performed using Merck silica gel 60 .

\section{Infrared spectroscopy}

Fourier transform infrared (FTIR) spectra were acquired on a Shimazu FTIR-8400S spectrometer equipped with a Golden Gate ATR (attenuated total reflection) system.

Spectra were recorded over a range of $4000-400 \mathrm{~cm}^{-1}$ with a resolution of $0.01 \mathrm{~cm}^{-1}$ (16, number of scans). Abbreviations used are: s, strong; $\mathrm{m}$, medium and $\mathrm{w}$, weak.

\section{${ }^{1} \mathrm{H}$-NMR, ${ }^{13} \mathrm{C}$-NMR measurements}

High resolution ${ }^{1} \mathrm{H}$ - and ${ }^{13} \mathrm{C}-\mathrm{NMR}$ spectra were recorded on a Bruker AM $300 \mathrm{MHz}$.

\section{Inductively coupled plasma (ICP)}

ICP measurements were recorded on a Perkin Elmer Optical Emission Spectrometer, Optima 7000 DV.

\section{A synthesis of the ligands}

Ligands were synthesized based on a two-step reaction:

First the nicotinic (or isonicotinic acid) is chlorinated to avoid for a second time the nucleophilic substitution of this chloride by the alcohol of the polyethylene glycols (Scheme 2).

\section{Ligand L3i}

$2 \mathrm{~g}$ of isonicotinic acid $(0.016 \mathrm{~mol})$ are dissolved in $100 \mathrm{~mL}$ of dimethylchloride. In an ice bath and under mixing $1.4 \mathrm{~mL}$ of oxalyl chloride $(0.016 \mathrm{~mol})$ is added dropwise. The reaction occurs overnight at room temperature. The system is connected to a trap of $\mathrm{NaOH}$ to absorb formed $\mathrm{HCl}$. The precipitate (isonicotinic acid chloride) is filtered and dried. Then $2 \mathrm{~g}$ of isonicotinic chloride $(0.014 \mathrm{~mol})$ are dissolved in $40 \mathrm{~mL}$ of toluene with $2.12 \mathrm{~g}(0.024 \mathrm{~mol})$ of $\mathrm{Et}_{3} \mathrm{~N}$ and $0.93 \mathrm{~mL}(1.05 \mathrm{~g}$, $0.007 \mathrm{~mol}$ ) of triethylene glycol. The reaction occurs overnight under reflux. The organic phase is extracted four times with DMC, and washed twice with water and once with saturated $\mathrm{NaHCO}_{3}$-solution. The resulting product is purified on a silica column eluting with a $6: 2$ hexane-ethyl acetate mixture.

Yield: $40 \%$.

IR $\left(\mathrm{cm}^{-1}\right): \nu(\mathrm{Ar}-\mathrm{H}) 3083.0 \mathrm{~s}, \nu(-\mathrm{HC}-\mathrm{H}) 2957.7 \mathrm{~s}, \nu(\mathrm{C}=\mathrm{O})$ $1714.5 \mathrm{~s}, \nu(\mathrm{C}=\mathrm{C}) 1588.5 \mathrm{~m}, \nu(\mathrm{ArC}-\mathrm{C}, \mathrm{C}=\mathrm{N}), 1415.4 \mathrm{~s}, \nu(\mathrm{CO}-\mathrm{O})$ $1273.7 \mathrm{~s}, \nu(-\mathrm{C}-\mathrm{O}) 1108.8 \mathrm{~s}, \nu(\mathrm{ArC}-\mathrm{H}) 738.9 \mathrm{~m}$.

${ }^{1} \mathrm{H}$ NMR $\left(\mathrm{CD}_{3} \mathrm{Cl}\right) \mathrm{ppm} 8.49(\mathrm{~d}, J=4.09 \mathrm{~Hz}, 2 \mathrm{H}), 7.59$ (br. s, $2 \mathrm{H}), 4.11-4.39$ (m, $2 \mathrm{H}), 3.79$ (br. s, $2 \mathrm{H}), 3.57$ (d, J = 4.09 Hz, 2 H), 3.34-3.51 (m, 8 H), 3.31 (br. s, 2 H).

${ }^{13} \mathrm{C}$ NMR $\left(\mathrm{CD}_{3} \mathrm{Cl}\right)$ ppm 164.42, 164.38, 149.86, 136.83, 122.46, 77.52, 76.80, 72.19, 70.00, 69.87, 69.65, 69.45, 68.31, $64.30,60.74$.

\section{Ligand L3n}

The same procedure as for $\mathbf{L} \mathbf{3} \mathbf{i}$ is used but instead of isonicotinic acid, nicotinic acid is used.

Yield: $35 \%$.

${ }^{1} \mathrm{H}$ NMR $\left(\mathrm{CD}_{3} \mathrm{Cl}\right)$ ppm 9.10 (br. s, $2 \mathrm{H}$ ), 8.64 (br. s, $2 \mathrm{H}$ ), $8.17(\mathrm{~d}, J=7.72 \mathrm{~Hz}, 2 \mathrm{H}), 7.25(\mathrm{~s}, 1 \mathrm{H}), 7.28(\mathrm{~s}, 1 \mathrm{H}), 4.38(\mathrm{t}, J=$ $4.54 \mathrm{~Hz}, 4 \mathrm{H}), 3.68-3.89$ (m, $4 \mathrm{H}), 3.61$ (s, $6 \mathrm{H})$.

${ }^{13} \mathrm{C}$ NMR $\left(\mathrm{CD}_{3} \mathrm{Cl}\right) \mathrm{ppm} 165.16,150.54,137.51,123.22$, $72.62,70.82,70.49,69.08,64.84,61.85$.

\section{Ligand L4i}

The same reaction as for $\mathbf{L} 3 \mathbf{i}$ is used but instead of triethylene glycol, $1.36 \mathrm{~g}(0.007 \mathrm{~mol})$ of tetraethylene glycol is used.

Yield: $45 \%$.

IR $\left(\mathrm{cm}^{-1}\right): \nu(\mathrm{Ar}-\mathrm{H}) 3115.1 \mathrm{~s}, \nu(-\mathrm{HC}-\mathrm{H}) 2987.2 \mathrm{~s}, \nu(\mathrm{C}=\mathrm{O})$ $1723.8 \mathrm{~s}, \nu(\mathrm{C}=\mathrm{C}) 1534.2 \mathrm{~m}, \nu(\mathrm{ArC}-\mathrm{C}, \mathrm{C}=\mathrm{N})$.

$1412.1 \mathrm{~s}, \nu(\mathrm{CO}-\mathrm{O}) 1278.8 \mathrm{~s}, \nu(-\mathrm{C}-\mathrm{O}) 1045.3 \mathrm{~s}, \nu(\mathrm{ArC}-\mathrm{H})$ $746.2 \mathrm{~m}$.

${ }^{1} \mathrm{H}$ NMR $\left(\mathrm{CD}_{3} \mathrm{Cl}\right) \mathrm{ppm} 8.49(\mathrm{~d}, J=4.09 \mathrm{~Hz}, 2 \mathrm{H}), 7.59$ (br. s, $2 \mathrm{H}$ ), 4.11-4.39 (m, $2 \mathrm{H}$ ), 3.79 (br. s, $2 \mathrm{H}$ ), 3.57 (d, $J=4.09 \mathrm{~Hz}$, $2 \mathrm{H}), 3.34-3.51$ (m, $8 \mathrm{H}), 3.31$ (br. s, $2 \mathrm{H}$ ).

${ }^{13} \mathrm{C}$ NMR $\left(\mathrm{CD}_{3} \mathrm{Cl}\right) \mathrm{ppm} 164.42,164.38,149.86,136.83$, 122.46, 77.52, 76.80, 72.19, 70.00, 69.87, 69.65, 69.45, 68.31, $64.30,60.74$.

\section{Ligand L4n}

The same procedure is used as for L4i but instead of isonicotinic acid, nicotinic acid is used.

Yield: $40 \%$. 
${ }^{1} \mathrm{H}$ NMR $\left(\mathrm{CD}_{3} \mathrm{Cl}\right)$ ppm 9.21 (br. s, $2 \mathrm{H}$ ), 8.75 (br. s, $2 \mathrm{H}$ ), $8.28(\mathrm{~d}, J=8.17 \mathrm{~Hz}, 2 \mathrm{H}), 7.36(\mathrm{dd}, J=7.27,5.00 \mathrm{~Hz}, 2 \mathrm{H})$, 4.33-4.64 (m, $4 \mathrm{H}), 3.72-3.96$ (m, $4 \mathrm{H}), 3.65$ (br. s, $9 \mathrm{H}$ ).

${ }^{13} \mathrm{C}$ NMR $\left(\mathrm{CD}_{3} \mathrm{Cl}\right)$ ppm 164.94, 153.23, 150.68, 136.97, 125.80, 123.16, 77.52, 76.81, 70.51, 68.90, 64.26.

\section{B Formation of the silver coordination compounds}

Typical synthesis (for complexes $\mathbf{1}$ and $\mathbf{5}$ to $\mathbf{9}$ ).

One (or two) equivalent of silver salt (depending on the desired ratio $\mathrm{M}: \mathrm{L}$ ) and one equivalent of ligand are mixed in methanol at a typical concentration of around 100-150 $\mathrm{mg}$ of the compound in $15 \mathrm{~mL}$ of the solvent. The reaction occurs during $c a .24$ hours at room temperature. In the case of solubility problems, the reaction solution in the Schlenk tube is heated under reflux.

After filtration, the method of slow diffusion is used to obtain a single crystalline product. In the bottom of the flask the mother solution is deposited, representing $c a$. $30 \%$ of the total volume of the solution. On top of this, a second phase is carefully layered with a syringe in order not to mix the two phases. Slow diffusion occurs at room temperature. After one to six months, crystals are obtained.

The syntheses of compounds $\mathbf{2}$ and $\mathbf{4}$ are following the same principle of slow diffusion by layering but in place of $\mathrm{MeOH}$ and hexane, THF and $\mathrm{CH}_{3} \mathrm{CN}$ are used. Compound 3 is obtained from an $\mathrm{H}$-tube using $\mathrm{CH}_{3} \mathrm{CN}$ and THF.

\section{Compound 1: $\left[\left\{\mathrm{Ag}(\mathrm{L} 3 \mathrm{i}) \mathrm{NO}_{3}\right\}\left(\mathrm{H}_{2} \mathrm{O}\right)_{2}\right]$}

$100 \mathrm{mg}(0.27 \mathrm{mmol})$ of $\mathbf{L} 3 \mathbf{i}$ and $47 \mathrm{mg}(0.27 \mathrm{mmol})$ of $\mathrm{AgNO}_{3}$ are dissolved in THF and heated under reflux for 24 hours. After filtration, $1 \mathrm{~mL}$ of the solution is placed in a flask. $0.5 \mathrm{~mL}$ of water and $3 \mathrm{~mL}$ of hexane are added carefully without mixing.

The crystals are obtained after six months at room temperature in the dark.

Yield: $26 \mathrm{mg}(0.046 \mathrm{mmol}), 17 \%$ calc. with respect to $\mathrm{AgNO}_{3}$.

ICP Ag: calculated $18.92 \%$, measured $20.46 \%$.

IR $\left(\mathrm{cm}^{-1}\right): \nu(-\mathrm{O}-\mathrm{H}) 3428.4$ broad, $\nu(\mathrm{Ar}-\mathrm{H}) 3073.8 \mathrm{~s}, \nu(-\mathrm{HC}-$ H) $2885.6 \mathrm{~m}, \nu(\mathrm{C}=\mathrm{O}) 1719.3 \mathrm{~s}, \nu(\mathrm{C}=\mathrm{C}) 1601.0 \mathrm{~s}, \nu(\mathrm{ArC}-\mathrm{C}$, $\mathrm{C}=\mathrm{N}) 1430.7 \mathrm{~s}, \nu\left(\mathrm{NO}_{3}\right) 1352.3-1284.0 \mathrm{~s}, \nu(-\mathrm{C}-\mathrm{O}) 1090.0 \mathrm{~s}$, $\nu(\mathrm{ArC}-\mathrm{H}) 695.5 \mathrm{~s}$.

\section{Compound 2: $\left[\left\{\mathrm{Ag}(\mathrm{L3i}) \mathrm{NO}_{3}\right\}\left(\mathrm{H}_{2} \mathrm{O}\right)\right]$}

A solution of THF containing $35.7 \mathrm{mg}$ of $\mathbf{L 3} \mathbf{i}(0.09 \mathrm{mmol})$ and $25 \mathrm{mg}$ of $\mathrm{AgNO}_{3}(0.09 \mathrm{mmol})$ was stirred together for an hour. Afterwards the solution was filtered and deposited in capillaries. Single crystals of the complex suitable for X-ray diffraction were able to be collected the next day. After two days crystals are formed in the vessel where the filtrate was collected.

Yield: $19.1 \mathrm{mg}$ (0.02 $\mathrm{mmol}), 48 \%$ calc. with respect to $\mathrm{AgNO}_{3}$.

Anal. calcd for: C 47.56, H 4.44, N 9.25\%. Found: C 45.2, H 5.1, N 9.1\%.
IR $\left(\mathrm{cm}^{-1}\right): \nu(\mathrm{Ar}-\mathrm{H}) 3098.7 \mathrm{~s}, \nu(-\mathrm{HC}-\mathrm{H}) 2957.7 \mathrm{~s}, \nu(\mathrm{C}=\mathrm{O})$ $1730.1 \mathrm{~s}, \nu(\mathrm{C}=\mathrm{C}) 1548.9 \mathrm{w}, \nu(\mathrm{ArC}-\mathrm{C}, \mathrm{C}=\mathrm{N}) 1407.2 \mathrm{w} \mathrm{s}, \nu(\mathrm{NO} 3)$ $1391.5-1187.2 \mathrm{~s}, \nu(-\mathrm{C}-\mathrm{O}) 1116.3 \mathrm{~s}, \nu(\mathrm{ArC}-\mathrm{H}) 691.0 \mathrm{~m}$.

\section{Compound 3: $\left[\mathrm{Ag}(\mathrm{L} 3 \mathrm{i}) \mathrm{O}_{3} \mathrm{SCF}_{3}\right]$}

Crystals of 3 were obtained by layering an acetonitrile solution of silver triflate $(30 \mathrm{mg}, 0.17 \mathrm{mmol}$, in $6 \mathrm{~mL}$ ) onto a THF solution containing L3i (64 mg, $0.17 \mathrm{mmol}$, in $15 \mathrm{~mL}$ ). After 1 week of slow evaporation single crystals of medium quality were isolated and measured. Slow diffusion of $20 \mathrm{~mL}$ THF linking $5 \mathrm{~mL}$ of a silver triflate solution in water and $5 \mathrm{~mL}$ of the ligand in THF in an " $\mathrm{H}$ "-shaped tube affords the same crystal structure after 45 days.

Yield: $50 \mathrm{mg}(0.08 \mathrm{mmol}), 48 \%$ calculated with respect to $\mathrm{AgSO}_{3} \mathrm{CF}_{3}$.

Anal. calcd for: C 36.9, H 3.27, N 4.54\%. Found: C 36.8, H $3.30, \mathrm{~N} 4.58 \%$.

IR $\left(\mathrm{cm}^{-1}\right): \nu(\mathrm{Ar}-\mathrm{H}) 3065.3 \mathrm{~s}, \nu(-\mathrm{HC}-\mathrm{H}) 2948.4 \mathrm{~s}, \nu(\mathrm{C}=\mathrm{O})$ $1731.1 \mathrm{~s}, \quad \nu(\mathrm{C}=\mathrm{C}) \quad 1543.9 \mathrm{w}, \quad \nu(\mathrm{ArC}-\mathrm{C}, \mathrm{C}=\mathrm{N}) 1422.3 \mathrm{w}$, $\nu(\mathrm{SO} 3 \mathrm{CF} 3) 1267.7 \mathrm{~s}$, broad, $\nu\left(\mathrm{SO}_{3} \mathrm{CF}_{3}\right) 1102.6 \mathrm{~s}$, broad, $\nu(\mathrm{ArC}-$ H) $631.6 \mathrm{~m}$.

\section{Compound 4: $\left[\mathrm{Ag}(\mathrm{L3i}) \mathrm{PF}_{6}\right]_{2}$}

$15 \mathrm{mg}$ of $\mathbf{L 3 i}(0.04 \mathrm{mmol})$ and $10.7 \mathrm{mg}(0.04 \mathrm{mmol})$ of $\mathrm{AgPF}_{6}$ were stirred in a $\mathrm{CH}_{3} \mathrm{CN}$ solution $(5 \mathrm{~mL})$ in a dark place. $3 \mathrm{~mL}$ of EtOEt were layered over the filtered solution, affording single colorless crystals suitable for X-ray crystallography after slow evaporation in a few days. Single crystals suitable for X-ray are obtained in the solution vessel.

Yield: $15.4 \mathrm{mg}$ (0.02 $\mathrm{mmol}), 63 \%$ calc. with respect to $\mathrm{AgPF}_{6}$.

Anal. calcd for: C 35.24, H 3.29, N 4.57\%. Found: C 34.9, H $3.32, \mathrm{~N} 4.5 \%$.

IR $\left(\mathrm{cm}^{-1}\right): \nu(-\mathrm{HC}-\mathrm{H}) 2918.7 \mathrm{~s}, \nu(\mathrm{C}=\mathrm{O}) 1716.5 \mathrm{~s}, \nu(\mathrm{C}=\mathrm{C})$ $1510.1 \mathrm{~m}, \nu($ ArC-C, C $=\mathrm{N}) 1462.4 \mathrm{~m}, \nu(\mathrm{C}-\mathrm{O}) 1298.2 \mathrm{~s}, \delta(\mathrm{ArC}-\mathrm{H})$ $1054.5 \mathrm{~m}, \nu$ (PF6) 636.2-530.5 s, broad.

\section{Compound 5: $\left[\mathrm{Ag}(\mathrm{L3n}) \mathrm{NO}_{3}\right]$}

$40 \mathrm{mg}(0.235 \mathrm{mmol})$ of $\mathrm{AgNO}_{3}$ and $85 \mathrm{mg}(0.235 \mathrm{mmol})$ of $\mathbf{L 3 n}$ are mixed in $15 \mathrm{~mL}$ of $\mathrm{MeOH}$ during 3 days at room temperature. After filtration and deposition of $1 \mathrm{~mL}$ of the solution and $3 \mathrm{~mL}$ of hexane in a flask at room temperature and in the dark, crystals are obtained in one month.

Yield: $34.8 \mathrm{mg}(0.066 \mathrm{mmol}), 28 \%$ calc. with respect to $\mathrm{AgNO}_{3}$.

ICP Ag: calculated 20.21\%, measured $22.16 \%$.

IR $\left(\mathrm{cm}^{-1}\right): \nu(\mathrm{Ar}-\mathrm{H}) 3073.4 \mathrm{~s}, \nu(-\mathrm{HC}-\mathrm{H}) 2884.5 \mathrm{~s}, \nu(\mathrm{C}=\mathrm{O})$ $1719.9 \mathrm{~s}, \nu(\mathrm{C}=\mathrm{C}) 1601.0 \mathrm{~s}, \nu(\mathrm{ArC}-\mathrm{C}, \mathrm{C}=\mathrm{N}) 1474.7 \mathrm{w}, \nu\left(\mathrm{NO}_{3}\right)$ 1364.3-1283.8 s, $\nu(-\mathrm{C}-\mathrm{O})$ 1090.0, $\nu(-\mathrm{C}-\mathrm{O}) 1090.5$ s, (ArC-H) $695.6 \mathrm{~s}$.

\section{Compound 6: $\left[\mathrm{Ag}_{2}(\mathrm{L3n})\left(\mathrm{NO}_{3}\right)_{2}\right]$}

$40 \mathrm{mg}(0.235 \mathrm{mmol})$ of $\mathrm{AgNO}_{3}$ and $42 \mathrm{mg}(0.117 \mathrm{mmol})$ of $\mathbf{L 3 n}$ are mixed in $15 \mathrm{~mL}$ of $\mathrm{MeOH}$ and placed under reflux during three days. After filtration and deposition of $1 \mathrm{~mL}$ of the 
solution in a flask, $3 \mathrm{~mL}$ of hexane are added. After one month at room temperature and in the dark, crystals are obtained.

Yield: $51.6 \mathrm{mg}, 63 \%$ calc. with respect to $\mathrm{AgNO}_{3}$.

ICP Ag: calculated $30.63 \%$, measured $32.6 \%$.

IR $\left(\mathrm{cm}^{-1}\right): \nu(\mathrm{Ar}-\mathrm{H}) 3073.1 \mathrm{~s}, \nu(-\mathrm{HC}-\mathrm{H}) 2884.2 \mathrm{~s}, \nu(\mathrm{C}=\mathrm{O})$ $1719.2 \mathrm{~s}, \nu(\mathrm{C}=\mathrm{C}) 1600.8 \mathrm{~s}, \nu(\mathrm{ArC}-\mathrm{C}, \mathrm{C}=\mathrm{N}) 1430.6 \mathrm{~s}, \nu\left(\mathrm{NO}_{3}\right)$ $1364.0 \mathrm{~s}-1280.0 \mathrm{~s}, \nu(-\mathrm{C}-\mathrm{O}) 1089.8 \mathrm{~s}, \nu(\mathrm{ArC}-\mathrm{H}) 695.5 \mathrm{~s}$.

\section{Compound 7: $\left[\mathrm{Ag}(\mathrm{L4i}) \mathrm{O}_{3} \mathrm{SCF}_{3}\right]_{2}$}

$300 \mathrm{mg}(0.742 \mathrm{mmol})$ of L4i and $191 \mathrm{mg}(0.742 \mathrm{mmol})$ of $\mathrm{AgCF}_{3} \mathrm{SO}_{3}$ are dissolved in $20 \mathrm{~mL}$ of $\mathrm{MeOH}$ and heated to $30{ }^{\circ} \mathrm{C}$ during three days. After filtration, $1 \mathrm{~mL}$ of the solution is placed in a flask. On top of this phase, $3 \mathrm{~mL}$ of hexane are added. After four months at room temperature and in the dark, crystals are obtained.

Yield: $201 \mathrm{mg}$ ( $0.304 \mathrm{mmol}), 41 \%$ with respect to $\mathrm{AgCF}_{3} \mathrm{SO}_{3}$. ICP Ag: calculated $16.20 \%$, measured $17.16 \%$.

IR $\left(\mathrm{cm}^{-1}\right): \nu(\mathrm{O}-\mathrm{H}) 3434.5$ broad, $\nu(\mathrm{Ar}-\mathrm{H}) 3075.5 \mathrm{~s}, \nu(-\mathrm{HC}-\mathrm{H})$ 2922.6, $\nu(\mathrm{C}=\mathrm{O}) 1731.8 \mathrm{~s}, \nu(\mathrm{C}=\mathrm{C}) 1612.7 \mathrm{~s}, \nu(\mathrm{ArC}-\mathrm{C}, \mathrm{C}=\mathrm{N})$ $1421.8 \mathrm{~s}, \nu\left(\mathrm{SO}_{3} \mathrm{CF}_{3}\right) 1221.6 \mathrm{~s}, \nu(-\mathrm{C}-\mathrm{O}) 1064.3 \mathrm{~s}, \nu(\mathrm{ArC}-\mathrm{H})$ $699.3 \mathrm{~s}$.

\section{Compound 8: $\left[\mathrm{Ag}(\mathrm{L4n}) \mathrm{NO}_{3}\left(\mathrm{CH}_{3} \mathrm{OH}\right)\right]_{2}$}

$42 \mathrm{mg}(0.247 \mathrm{mmol})$ of $\mathrm{AgNO}_{3}$ and $100 \mathrm{mg}(0.247 \mathrm{mmol})$ of L4n are dissolved in $5 \mathrm{~mL}$ of $\mathrm{MeOH}$ and heated to $60{ }^{\circ} \mathrm{C}$ for 30 minutes. After filtration, $1 \mathrm{~mL}$ of the solution is placed in a flask with $0.5 \mathrm{~mL}$ of EtOH. After six weeks at room temperature and in the dark, crystals are obtained and measured.

Yield: $16.46 \mathrm{mg}(0.027 \mathrm{mmol}), 11 \%$ calc. with respect to $\mathrm{AgNO}_{3}$.

ICP Ag: calculated $17.67 \%$, measured $19.17 \%$.

IR $\left(\mathrm{cm}^{-1}\right): \nu(-\mathrm{O}-\mathrm{H}) 3441.3$ broad, $\nu(\mathrm{Ar}-\mathrm{H}) 3071.8 \mathrm{~s}, \nu(-\mathrm{HC}-$ H) $2871.5 \mathrm{~m}, \nu(\mathrm{C}=\mathrm{O}) 1719.5 \mathrm{~s}, \nu(\mathrm{C}=\mathrm{C}) 1599.2 \mathrm{~s}, \nu(\mathrm{ArC}-\mathrm{C}$, $\mathrm{C}=\mathrm{N}) 1432.5 \mathrm{~s}, \nu\left(\mathrm{NO}_{3}\right) 1385.0 \mathrm{~s}, 1280.0 \mathrm{~s}, \nu(-\mathrm{C}-\mathrm{O}) 1089.7 \mathrm{~s}$, $\nu(\mathrm{ArC}-\mathrm{H}) 699.0 \mathrm{~s}$.

\section{Compound 9: $\left[\mathrm{Ag}_{2}(\mathrm{~L} 4 n)\left(\mathrm{NO}_{3}\right)_{2}\right]_{2}$}

$280 \mathrm{mg}(0.693 \mathrm{mmol})$ of $\mathbf{L 4 n}$ and $118 \mathrm{mg}(0.694 \mathrm{mmol})$ of $\mathrm{AgNO}_{3}$ are heated in $15 \mathrm{~mL}$ of $\mathrm{MeOH}$ to reflux overnight. After filtration and deposition in a flask, $3 \mathrm{~mL}$ of hexane are added. After two months at room temperature and in the dark, crystals are obtained.

Yields: $278.8 \mathrm{mg}$ ( $0.375 \mathrm{mmol}), 54 \%$ with respect to $\mathrm{AgNO}_{3}$.

ICP Ag: calculated $28.82 \%$, measured $26.43 \%$.

IR $\left(\mathrm{cm}^{-1}\right): \nu(\mathrm{Ar}-\mathrm{H}) 3071.3 \mathrm{~s}, \nu(-\mathrm{HC}-\mathrm{H}) \quad 2881.2, \nu(\mathrm{C}=\mathrm{O})$ $1718.8 \mathrm{~s}, \nu(\mathrm{C}=\mathrm{C}) 1600.9 \mathrm{~s}, \nu(\mathrm{ArC}-\mathrm{C}, \mathrm{C}=\mathrm{N}) 1434.9 \mathrm{~s}, \nu\left(\mathrm{NO}_{3}\right)$ $1363.5 \mathrm{~s}-1285.1 \mathrm{~s}, \nu(-\mathrm{C}-\mathrm{O}) 1088.9 \mathrm{~s}, \nu(\mathrm{ArC}-\mathrm{H}) 699.0 \mathrm{~s}$.

\section{Single-crystal X-ray diffraction}

Prismatic single crystals of compounds 1-9 were carefully selected under a polarizing microscope. Compounds 1, 5-9 are glued in a loop and measured at $200 \mathrm{~K}$. Compounds $\mathbf{2 - 4}$ are fixed on a capillary and measured at $293 \mathrm{~K}$. Diffraction data were collected on a Stoe IPDS XArea diffractometer, using in all cases graphite monochromated Mo-K $\alpha$ radiation.
Absorption effect was also corrected by using Platon ${ }^{35}$ for compounds 1, 5-9. The structures 1-9 were solved by direct methods (SHELXS 97 ${ }^{34}$ ) and then refined by the full-matrix least squares procedure based on $F^{2}$, using the SHELXL 97 computer program belonging to the WINGX software package. ${ }^{36}$ Anisotropic thermal parameters were assigned to the non-H atoms. The hydrogen atoms were generated geometrically.

\section{Representation of graphics}

Crystal graphics were carried out using POV-RAY and DIAMOND v3.0 softwares, WINGX softwares package. ${ }^{35}$

\section{Antimicrobial tests}

BaCterial Strains and GROWTH CONDItIONs. Staphylococcus (S.) epidermidis 1457 bacteria were freshly grown in tryptic soy broth (TSB) for $7 \mathrm{~h}$ at $37^{\circ} \mathrm{C}$ without shaking and then diluted $1: 100$ for an overnight $(\mathrm{ON})$ culture, which was used for the experiments. Bacterial numbers were estimated by determining the optical density at $600 \mathrm{~nm}$ and assessed by plating serial dilutions on Müller Hinton Agar (MHA).

IN VITRO ANTIMICROBIAL SUSCEPTIBILITY. A standard inoculum of 1 $\times 10^{5}$ to $5 \times 10^{5} \mathrm{CFU} \mathrm{mL} \mathrm{m}^{-1}$ of $S$. epidermidis 1457 was used. Minimal inhibitory and bactericidal concentrations (MIC and $\mathrm{MBC}$, respectively) of silver compounds for logarithmically growing bacteria were determined using a macrodilutions method according to the Clinical and Laboratory Standards Institute (CLSI) guidelines (Murray, P. R., E. J. Baron, J. H. Jorgensen, M. A. Pfaller, and R. H. Yolken (ed.). 2003. Manual of clinical microbiology, 7th ed. American Society for Microbiology, Washington, DC). The MIC was the lowest concentration of silver compounds that inhibited visible bacterial growth. The MBC was defined as the lowest concentration of silver compounds which killed $\geq 99.9 \%$ of the initial bacterial counts (i.e., $\geq 3 \log _{10}\left(\mathrm{CFU} \mathrm{mL} \mathrm{m}^{-1}\right)$ ) in $24 \mathrm{~h}$.

Agar INHIBITION ASSAYS. Agar inhibition assays were performed in dishes with a size of $24 \times 24 \mathrm{~cm}$ containing $160 \mathrm{~mL}$ agar. S. epidermidis 1457 was diluted to $10^{4}, 10^{6}$ and $10^{7} \mathrm{CFU} \mathrm{mL}^{-1}$ in the agar. Solutions of silver compounds were pipetted into the holes each of $1 \mathrm{~cm}$ diameter in the agar. The agar plates were incubated for $18 \mathrm{~h}$ at $37^{\circ} \mathrm{C}$, and the inhibition zones around the solutions of the silver compounds were measured.

\section{Biocompatibility tests}

Fibroblast cell culture. L-929 fibroblast murine cell lines (ATCC number: CCL-1) were used as a cell model to investigate the effects of material variations on soft tissue response. The fibroblast cultures were maintained in RPMI supplemented with $0.25 \mathrm{mM}$ HEPES, $10 \%$ fetal bovine serum, 1X NEEA, $1 \mathrm{mM}$ sodium pyruvate and $1 \%$ penicillin/streptomycin at $37^{\circ} \mathrm{C}$ in humidified air and $5 \% \mathrm{CO}_{2}$. Cultures were subdivided by trypsination using Trypsin-EDTA solution. The culture medium was changed every 3 days.

MTT ASSAY OF FIBROBLAST CELLS. A quantitative colorimetric MTT test was performed after 2, 3 and 4 days of culture to 
characterize cellular metabolism (vitality) and, by implication, proliferation. Cells were seeded at the right concentration onto the 96-well plates, grew for $24 \mathrm{~h}$ before adding the silver-compounds. As a control substrate for cell attachment and growth, fibroblasts were plated directly onto tissue culture polystyrene plastic. At day 2,3 and $4,10 \mu \mathrm{L}$ of MTT solution $\left[5 \mathrm{mg} \mathrm{mL}^{-1}\right.$ 3-(4,5-dimethylthiazol-2-yl)-2,5-diphenyl-tetrazolium bromide in PBS] was added to each well, and the cells were incubated at $37{ }^{\circ} \mathrm{C}$ for $4 \mathrm{~h}$. The reaction was stopped at $4{ }^{\circ} \mathrm{C}$ for hours. The medium was then removed and $100 \mu \mathrm{L}$ of dimethylsulfoxide was added to each well, followed by $30 \mathrm{~min}$ incubation at room temperature on a shaker. The optical density (OD) was measured at $540 \mathrm{~nm}$ with an ELISA Reader. The mean absorbance values were corrected for a blank (medium only) and results were reported as optical density.

\section{Acknowledgements}

The authors thank the Swiss National Science Foundation, the University of Fribourg and the Fribourg Center for Nanomaterials FriMat for generous support.

\section{Notes and references}

1 (a) J. Song, Z. Luo, D. K. Britt, H. Furukawa, O. M. Yaghi, K. I. Hardcastle and C. L. Hill, J. Am. Chem. Soc., 2011, 133, 16839-16846; (b) S. Wan, F. Gandara, A. Asano, H. Furukawa, A. Saeki, S. K. Dey, L. Liao, M. W. Ambrogio, Y. Y. Botros, X. Duan, S. Seki, J. F. Stoddart and O. M. Yaghi, Chem. Mater., 2011, 23, 4094-4097; (c) J. Gassensmith, H. Furukawa, R. A. Samldone, R. S. Forgan, Y. Y. Botros, O. M. Yaghi and J. F. Stoddart, J. Am. Chem. Soc., 2011, 133, 15312-15315; (d) K. M. Choi, H. J. Jeon, J. K. Kang and O. M. Yaghi, J. Am. Chem. Soc., 2011, 133, 11920-11923; (e) A. J. Cairns, J. A. Perman, L. Wojtas, V. Ch. Kravtsov, M. H. Alkordi, M. Eddaoudi and M. J. Zaworotko, J. Am. Chem. Soc., 2008, 130, 1560-1561; (f) F. Nouar, J. F. Eubank, T. Bousquet, L. Wojtas, M. J. Zaworotko and M. Eddaoudi, J. Am. Chem. Soc., 2008, 130, 1833-1835; $(g)$ M. Fujita, Y. J. Kwon, O. Sasaki, K. Yamaguchi and K. Ogura, J. Am. Chem. Soc., 1995, 117, 7287.

2 (a) C. Janiak, Angew. Chem., 1997, 109, 1499-1502; (b) C. Janiak, Dalton Trans., 2003, 2781-2804; (c) S. R. Batten, B. F. Hoskins and R. Robson, J. Am. Chem. Soc., 1995, 117, 5385-5386.

3 (a) S. R. Batten and R. Robson, Angew. Chem., 1998, 110, 1558-1595; (b) M. Eddaoudi, D. B. Moler, H. Li, B. Chen, T. M. Reineke, M. O'Keeffe and O. M. Yaghi, Acc. Chem. Res., 2001, 34, 319-330; (c) O. M. Yaghi, M. O'Keeffe, N. W. Ockwig, H. K. Chae, M. Eddaoudi and J. Kim, Nature, 2003, 423, 705-714; (d) O. M. Yaghi, H. Li, C. Davis, D. Richardson and T. L. Groy, Acc. Chem. Res., 1998, 31, 474-484; (e) A. J. Blake, N. R. Champness, P. Hubberstey,
W.-S. Li, M. A. Withersby and M. Schröder, Coord. Chem. Rev., 1999, 183, 117-138; (f) A. N. Khlobystov, A. J. Blake, N. R. Champness, D. A. Lemenovskii, A. G. Majouga, N. V. Zyk and M. Schröder, Coord. Chem. Rev., 2001, 222, 155-192; (g) P. J. Hagrman, D. Hagrman and J. Zubieta, Angew. Chem., 1999, 111, 2798-2848; (h) S. Kitagawa and S. Kawata, Coord. Chem. Rev., 2002, 224, 11-34; (i) S. Kitagawa and M. Munakata, Trends Inorg. Chem., 1993, 3, 437-462; (j) M. Munakata, Adv. Inorg. Chem., 1998, 46, 173-303; (k) M. J. Zaworotko, Chem. Soc. Rev., 1994, 23, 283-288; (l) B. Moulton and M. J. Zaworotko, Chem. Rev., 2001, 101, 1629-1658.

4 (a) A. N. Khlobystov, A. J. Blake, N. R. Champness, D. A. Lemenovskii, A. G. Majouga, N. V. Zyk and M. Schröder, Coord. Chem. Rev., 2001, 222, 155-192; (b) K. Biradha, C. Seward and M. J. Zaworotko, Angew. Chem., 1999, 111, 584-587; (c) B. F. Hoskins, R. Robson and D. A. Slizys, J. Am. Chem. Soc., 1997, 119, 2952-2953.

5 (a) J. Konnert and D. Britton, Inorg. Chem., 1966, 5, 1193; S. R. Batten, B. F. Hoskins and R. Robson, New J. Chem., 1998, 22, 173-175; (b) B. F. Abrahams, S. R. Batten, B. F. Hoskins and R. Robson, Inorg. Chem., 2003, 42, 26542664; (c) O.-S. Jung, Y. J. Kim, K. M. Kim and Y.-A. Lee, J. Am. Chem. Soc., 2002, 124, 7906-7907; (d) K. V. Domasevitch, I. Boldog, E. B. Rusanov, J. Hunger, S. Blaurock, M. Schroder and J. Sieler, Z. Anorg. Allg. Chem., 2005, 631, 1095-1100; (e) D. M. Proserpio, CrystEngComm, 2003, 5, 269; D. M. Proserpio, Coord. Chem. Rev., 2003, 246, 247; $(f)$ S. Banfi, L. Carlucci, E. Caruso, G. Ciani and D. M. Proserpio, Cryst. Growth Des., 2004, 4, 29-32; (g) D. Whang and K. Kim, J. Am. Chem. Soc., 1997, 119, 451-452; (h) N. R. Brooks, A. J. Blake, N. R. Champness, J. W. Cunningham, P. Hubberstey, S. J. Teat, C. Wilson and M. Schroder, J. Chem. Soc., Dalton Trans., 2001, 2530-2538; (i) L. Carlucci, G. Ciani, D. M. Proserpio and S. Rizzato, CrystEngComm, 2002, 4(22), 121-129; (j) L. Carlucci, G. Ciani, D. M. Proserpio and S. Rizzato, CrystEngComm, 2002, 4, 413-425; ( $k$ ) Y.-B. Dong, P. Wang, R.-Q. Huang and M. D. Smith, Inorg. Chem., 2004, 43, 4727-4739.

6 (a) S. Q. Liu, H. Konaka, T. Kuroda-Sowa, M. Maekawa, Y. Suenaga, G. L. Ning and M. Munakata, Inorg. Chim. Acta, 2005, 358, 919-926; (b) L. Carlucci, G. Ciani, D. M. Proserpio and A. Sironi, J. Chem. Soc., Chem. Commun., 1994, 2755; (c) A. Klein, E. Graf, M. W. Hosseini and A. De Cian, New J. Chem., 2001, 25, 207-209; (d) L. Carlucci, G. Ciani, D. M. Proserpio and S. Rizzato, Chem.-Eur. J., 2002, 8, 1520-1526; (e) K. A. Hirsch, D. Venkataraman, S. R. Wilson, J. S. Moore and S. Lee, J. Chem. Soc., Chem. Commun., 1995, 2199-2200; (f) J.-P. Zhang, Y.-Y. Lin, W.-X. Zhang and X.-M. Chen, J. Am. Chem. Soc., 2005, 127, 14162-14163; (g) M. A. Withersby, A. J. Blake, N. R. Champness, P. Hubberstey, W.-S. Li and M. Schroder, Angew. Chem., Int. Ed. Engl., 1997, 36, 2327; (h) L. Carlucci, G. Ciani, P. Macchi, D. M. Proserpio and S. Rizzato, Chem.-Eur. J., 1999, 5, 237-243; (i) Y. M. Chow and D. Britton, Acta 
Crystallogr., Sect. B, 1974, 30, 1117; (j) L. Carlucci, G. Ciani, P. Macchi, D. M. Proserpio and S. Rizzato, Chem.-Eur. J., 1999, 5, 237-243; (k) S. Muthu, J. H. K. Yip and J. J. Vittal, J. Chem. Soc., Dalton Trans., 2002, 4561-4568; (l) L. Carlucci, G. Ciani, D. M. Proserpio and A. Sironi, Chem. Commun., 1996, 1393-1394; (m) C. J. Sumby and M. J. Hardie, Cryst. Growth Des., 2005, 5, 1321-1324; (n) A. B. Mallik, S. Lee and E. B. Lobkvsky, Cryst. Growth Des., 2005, 5, 609-616; (o) F. Robinson and M. J. Zaworotko, J. Chem. Soc., Chem. Commun., 1995, 2413-3414; (p) O. M. Yaghi and H. Li, J. Am. Chem. Soc., 1996, 118, 295-296.

7 (a) M. A. Withersby, A. J. Blake, N. R. Champness, P. Hubberstey, W.-S. Li and M. Schroder, Angew. Chem., Int. Ed. Engl., 1997, 36, 2327-2329; (b) A. N. Khlobystov, N. R. Champness, C. J. Roberts, S. J. B. C. Tendler Thompson and M. Schroeder, CrystEngComm, 2002, 4, 426-431; (c) H.-J. Kim, W.-C. Zin and M. Lee, J. Am. Chem. Soc., 2004, 126(22), 7009-7014; (d) Y.-P. Ren, X.-J. Kong, L.-S. Long, R.B. Huang and L.-S. Zheng, Cryst. Growth Des., 2006, 6(2), 572-576.

8 (a) X.-H. Bu, Y.-B. Xie, J.-R. Li and R.-H. Zhang, Inorg. Chem., 2003, 42(23), 7422-7430; (b) D. L. Reger, R. F. Semeniuc and M. D. Smith, Eur. J. Inorg. Chem., 2003, 18, 3480-3494; (c) E. C. Constable, C. E. Housecroft and T. Kulke, Chem. Comm., 1998, 23, 2659-2660.

9 (a) A. J. Blake, G. Baum, N. R. Champness, S. S. M. Chung, P. A. Cooke, D. Fenske, A. N. Khlobystov, D. A. Lemenovskii, W.-S. Li and M. Schroder, J. Chem. Soc., Dalton Trans., 2000, 4285-4291; (b) B. Britton, Acta Crystallogr., Sect. C: Cryst. Struct. Commun., 1991, 47, 2646-2647; D. Britton and J. D. Dunitz, Acta Crystallogr., 1965, 19, 662668; (c) D. Braga, M. Polito, D. D’Addario and F. Grepioni, Cryst. Growth Des., 2004, 4(6), 1109-1112; (d) D. V. Soldatov, A. T. Henegouwen, G. D. Enright, C. I. Ratcliffeand and J. A. Ripmeester, Inorg. Chem., 2001, 40(7), 1626-1636; (e) E. Tynan, P. Jensen, N. Kelly, P. Kruger, A. C. Lees, B. Moubaraki and S. M. Keith, Dalton Trans., 2004, 21, 3440-3447.

10 (a) K. T. Holman, H. H. Hammud, S. Isber and M. Tabbal, Polyhedron, 2005, 24(2), 221-228; (b) S. Kawata, S. Kitagawa, H. Kumagai, S. Iwabuchi and M. Katada, Inorg. Chim. Acta, 1998, 267(1), 143-145; (c) R. G. Vranka and E. L. Amma, Inorg. Chem., 1966, 5(6), 1020-1025.

11 (a) J. L. Manson, T. Lancaster, L. C. Chapon, S. J. Blundell, J. A. Schlueter, M. L. Brooks, F. L. Pratt, C. L. Nygren and J. S. Qualls, Inorg. Chem., 2005, 44(4), 989-995; (b) B. M. Wells, C. P. Landee, M. M. Turnbull, F. F. Awwadi and B. Twamley, J. Mol. Catal. A, 2005, 228(1-2), 117-123; (c) L. C. Tabares, J. A. R. Navarro and J. M. Salas, J. Am. Chem. Soc., 2001, 123(3), 383-387; (d) C. Naether and I. Jess, Eur. J. Inorg. Chem., 2004, 14, 2868-2876.

12 (a) O. M. Yaghi and H. Li, J. Am. Chem. Soc., 1996, 118(1), 295-296; (b) S. R. Batten, J. C. Jeffery and M. D. Ward, Inorg. Chim. Acta, 1999, 292(2), 231-237; (c) S. D. Huang, R.-G. Xiong, J. Han and B. R. Weiner, Inorg. Chim. Acta,
1999, 294(1), 95-98; (d) H. Hou, Y. Wei, Y. Fan, C. Du, Y. Zhu, Y. Song, Y. Niu and X. Xin, Inorg. Chim. Acta, 2001, 319(1,2), 212-218; (e) S. Noro, S. Kitagawa, M. Kondo and K. Seki, Angew. Chem., Int. Ed. Engl., 2000, 39(12), 20822084; $(f)$ M. Du and X.-J. Zhao, Inorg. Chem. Commun., 2004, 7(9), 1056-1060; (g) F. Robinson and M. J. Zaworotko, Chem. Commun., 1995, 2413-2414; (h) H. W. Roesky and M. Andruh, Coord. Chem. Rev., 2003, 236(1-2), 91-119.

13 (a) Y.-B. Dong, R. C. Layland, M. D. Smith, N. G. Pschirer, U. H. F. Bunz and H.-C. Zur Loye, Inorg. Chem., 1999, 38 (13), 3056-3060; (b) H. Zhu, C. Huang, W. Huang and S. Gou, Inorg. Chem. Commun., 2004, 7(10), 1095-1099; (c) R. Wang, L. Han, L. Xu, Y. Gong, Y. Zhou, M. Hong and A. S. C. Chan, Eur. J. Inorg. Chem., 2004, 18, 3751-3763; (d) R. Horikoshi and M. Mikuriya, Cryst. Growth Des., 2005, 5(1), 223-230; (e) L. Carlucci, G. Ciani, D. W. v. Gundenberg and D. M. Proserpio, Inorg. Chem., 1997, 36(18), 3812-3813; (f) X.-M. Ouyang, B.-L. Fei, T.-a. Okamura, H.-W. Bu, W.-Y. Sun, W.-X. Tang and N. Ueyama, Eur. J. Inorg. Chem., 2003, 4, 618-627; (g) M. Du, X.-H. Bu, Y.-M. Guo, H. Liu, S. R. Batten, J. Ribas and T.C. W. Mak, Inorg. Chem., 2002, 41(19), 4904-4908; (h) B.-L. Fei, W.-Y. Sun, T.-a. Okamura, W.-X. Tang and N. Ueyama, New J. Chem., 2001, 25(2), 210-212; (i) R. Horikoshi, T. Mochida, N. Maki, S. Yamada and H. Moriyama, Dalton Trans., 2002, 1, 28-33; (j) G. K. Patra and I. Goldberg, Dalton Trans., 2002, 6, 1051-1057; (k) L.-C. Song, W.-X. Zhang, J.-Y. Wang and Q.-M. Hu, Transition Met. Chem., 2002, 27(5), 526-531; (l) A. J. Blake, N. R. Brooks, N. R. Champness, L. R. Hanton, P. Hubberstey and M. Schroder, Pure Appl. Chem., 1998, 70 (12), 2351-2357; $(m)$ R. L. LaDuca Jr., R. S. Rarig Jr., P. J. Zapf and J. Zubieta, Solid State Sci., 2000, 2(1), 39-45; (n) M.-L. Tong, X.-M. Chen, B.-H. Ye and S. W. Ng, Inorg. Chem., 1998, 37(20), 5278-5281; (o) T. Kawano, C.-X. Du, T. Araki and I. Ueda, Inorg. Chem. Commun., 2003, 6(2), 165-167; ( $p$ ) A. J. Blake, G. Baum, N. R. Champness, S. S. M. Chung, P. A. Cooke, D. Fenske, A. N. Khlobystov, D. A. Lemenovskii, W.-S. Li and M. Schroder, Dalton Trans., 2000, 23, 4285-4291; (q) S. Muthu, J. H. K. Yip and J. J. Vittal, Dalton Trans., 2001, 24, 3577-3584; (r) M.-L. Tong, Y.-M. Wu, J. Ru, X.-M. Chen, H.C. Chang and S. Kitagawa, Inorg. Chem., 2002, 41(19), 4846-4848; $(s)$ A. J. Blake, N. R. Champness, P. A. Cooke and J. E. B. Nicolson, Chem. Commun., 2000, 8, 665-666.

14 (a) B. Britton, Acta Crystallogr., Sect. C: Cryst. Struct. Commun., 1991, 47, 2646-2647; (b) D. Britton and J. D. Dunitz, Acta Crystallogr., 1965, 19, 662-668.

15 (a) Z. Liu, P. Liu, Y. Chen, J. Wang and M. Huang, New J. Chem., 2005, 29(3), 474-478; (b) T. Wu, D. Li, X.-L. Feng and J.-W. Cai, Inorg. Chem. Comm., 2003, 6(7), 886-890; (c) S. Corni and J. Tomasi, J. Chem. Phys., 2003, 118(14), 6481-6494; (d) S. Astilean and W. L. Barnes, J. Appl. Phys. B, 2002, 75(4-5), 591-594. 
16 (a) J. Kreth, D. Kim, M. Nguyen, G. Hsiao, R. Mito, M. K. Kang, N. Chugal and W. Shi, Open Dent. J., 2008, 2, 18-23; (b) L. F. Lo, M. Hayter, C. J. Chang, H. W. Hu and L. L. Lee, J. Clin. Nursing, 2008, 17(15), 1973-1985; (c) X. Yang, W. Yang, Q. Wang, H. Li, K. Wang, L. Yang and W. Lui, Talanta, 2010, 81(4-5), 1508-1512.

17 A. Y. Robin, J. L. Sague Doimeadios, A. Neels, T. Vig Slenters and K. M. Fromm, Inorg. Chim. Acta, 2007, 360, 212220.

18 T. Vig Slenters, I. Hauser-Gerspach, A. U. Daniels and K. M. Fromm, J. Mater. Chem., 2008, 18, 53595362.

19 P. S. Brunetto and K. M. Fromm, Chimia, 2008, 62-4, 249252.

20 P. S. Brunetto, J. L. Sagué, T. Vig Slenters, A. Y. Robin, R. Landmann, A. U. Daniels and K. M. Fromm, Materials, 2010, 3(5), 3407-3429.

21 P. S. Brunetto, T. Vig Slenters, R. Luginbühl, M. Otto, R. Landman and K. M. Fromm, Antimicrob. Agents Chemother., 2010, 54(10), 4208.

22 P. S. Brunetto and K. M. Fromm, Eur. Cells Mater., 2010, 20 (3), 29.

23 P. S. Brunetto, T. Vig Slenters and K. M. Fromm, Materials, 2011, 4(2), 355-367.

24 K. M. Fromm, J. L. Sague and L. Mirolo, Macromol. Symp., 2010, 291-292, 75-83.

25 J. L. Sague and K. M. Fromm, Cryst. Growth Des., 2006, 6, 1566-1568.

26 J. L. Sague, M. Meuwly and K. M. Fromm, CrystEngComm, 2008, 10, 1542-1549.
27 A. Y. Robin, J. L. Sague and K. M. Fromm, CrystEngComm, 2006, 8, 403-416.

28 A. Y. Robin, M. Meuwly, H. Goesmann and G. Bernardinelli, CrystEngComm, 2004, 6(60), 336-343.

29 A. Y. Robin, J. L. Sagué, A. Neels, T. V. Slenters and K. M. Fromm, Inorg. Chim. Acta, 2007, 360(1), 212-220.

30 J. L. Sagué Doimeadios, A. Y. Robin and K. M. Fromm, Chem. Commun., 2005, 4548-4550.

31 (a) T. Lang, A. Guenet, E. Graf, N. Kyritzaka and M. W. Hosseini, Chem. Commun., 2010, 3508-3510; (b) A. Jouaiti, M. W. Hosseini and N. Kyritsakas, Chem. Commun., 2003, 472-473.

32 (a) S. Belanger, M. Gilbertson, D. I. Yoon, C. L. Stern, X. Dang and J. T. Hupp, J. Chem. Soc., Dalton Trans., 1999, 3407-3411; (b) H. Duerr, H. Kilburg and S. Bossmann, Synthesis, 1990, 773-778; (c) G. R. Newkome, K. J. Theriot, V. K. Gupta, R. N. Balz and F. R. Fronczek, Inorg. Chim. Acta, 1986, 114(1), 21-23; (d) O. Piepers and R. M. Kellogg, J. Chem. Soc., Chem. Commun., 1978, 383-384.

33 (a) F. Gschwind, O. Sereda and K. M. Fromm, Inorg. Chem., 2009, 48(22), 10535-10547; (b) F. Gschwind and K. M. Fromm, Z. Anorg. Allg. Chem., 2011, 637, 1871-1879.

34 G. M. Sheldrick, SHELX-99, Program for Crystal Structure Refinement, University of Göttingen, Göttingen, 1999.

35 A. L. Spek, PLATON 1980-2011, Utrecht University, Padualaan 8, $3584 \mathrm{CH}$, Utrecht, The Netherlands.

36 L. J. Farrugia, WinGX-Version 1.80.05, Program for Crystal Structure Solution, Refinement and Analysis, University of Glasgow, J. Appl. Crystallogr., 1999, 32, 837-838. 